\title{
Application of Bias- and Variance-Corrected SST on Wintertime Precipitation Simulation of Regional Climate Model over East Asian Region
}

\author{
Seok-Woo Shin ${ }^{1,2} \cdot$ Tae-Jun Kim ${ }^{1} \cdot$ Jin-Uk Kim ${ }^{1} \cdot$ Tae-Young Goo ${ }^{1}$ - Young-Hwa Byun ${ }^{1}$ \\ Received: 7 May 2019 / Revised: 16 January 2020 / Accepted: 3 March 2020 / Published online: 8 May 2020 \\ (C) The Author(s) 2020
}

\begin{abstract}
In this study, the regional climate of East Asia was dynamically downscaled using Hadley Centre Global Environmental Model version 3-Regional Atmosphere (HadGEM3-RA) forced by the historical simulation data (1979-2005) of HadGEM2-AO produced by the National Institute of Meteorological Sciences (NIMS). To understand the impact of corrected SST on regional climate simulation, we integrated the experiments using uncorrected (UC_SST) and Bias- and Variance-corrected (BCVC_SST) HadGEM2-AO SST and used the simulated data driven by the ERA-Interim reanalysis data and HadGEM2-AO data. Examination of the spatial distribution, statistics, and interannual variation on wintertime precipitation over East Asia indicates that BCVC_SST reduced the overestimation of the climatological mean precipitation. In order to understand the impact of corrected SST on variability, we investigated the relationship between winter snowfall in South Korea and SST over East Asia. The negative correlation coefficient between the winter precipitation and the SST of the seas surrounding Korea appears in the result of observation data. The experiment result using BCVC_SST simulated the negative correlation between the winter snowfall and the SST around Korea more realistically than that of the simulations using UC_SST and HadGEM2-AO data. These results indicate that corrected SST helps to improve the variability of snowfall and SST simulated by HadGEM3-RA. However, time lag about the years when had peak point of SST appeared in the results compared between BCVC_SST experiment and observation data. The peak years shown in the result of the BCVC_SST experiment were similar to that of HadGEM2-AO data. At these results, even though the corrected SST improves climatological mean and variability of simulated data, it has the limitation not to overcome the error such as time lag showed in GCM SST. Additionally, the analysis of the snowfall in South Korea describes that SST is passively used for the source of snowfall and atmospheric variables mainly lead the intensity and the amount of snowfall.
\end{abstract}

Keywords HadGEM3-RA · Dynamical downscaling · Bias- and variance-corrected SST · Wintertime precipitation and snowfall · Cold surge

\section{Introduction}

The 4th and 5th assessment reports (AR4 or AR5) of the Intergovernmental Panel on Climate Change (IPCC) describe

Responsible Editor: Kyong-Hwan Seo.

Seok-Woo Shin

shinsw2012@gmail.com

1 National Institute of Meteorological Sciences, 33 Seohobuk-ro, Seogwipo-si, Jeju-do 63568, South Korea

2 Ulsan National Institute of Science and Technology, 50 UNIST-gil, Eonyang-eup, Ulju-gun, 44919 Ulsan, South Korea that high-impact weather and climate events related to global warming are occurring more frequently with the increase of human and material damage (IPCC 2014). Particularly, the enhancement in precipitable water according to atmospheric temperature increase may change spatial and temporal variations of precipitation features on global and regional scales (Kimoto 2005; Giorgi et al. 2011). So, for steady preparation and efficient adaptation of future climate, in particular, hydrological management, more reliable and detailed information concerning future climate changes are needed.

Previously, many studies of climate model showed that Global Climate Models (GCMs) present a large-scale characterization of the climate system (McAvaney and Coauthors 2001; IPCC 2014). However, it is insufficient 
to understand regional climate change with the simulated climate information of GCMs in the regional scale such as East Asia where has complex topographical and land surface characteristics because of dynamical reasons such as low-horizontal resolution and relatively less-realistic physical processes (Hong et al. 2011). Thus, Statistical Downscaling (SD) and Dynamical Downscaling (DD) using RCM were proposed as the alternative (SD: Paul et al. 2008; Yhang et al. 2017).

Here, Regional Climate Models (RCMs) of DD have been recognized the useful tool to obtain the added value and the meaningful information of regional future climate (Leung et al. 2003; Castro et al. 2005; Feser et al. 2011; Gao et al. 2011; Park et al. 2013; Hong and Kanamitsu 2014; Oh et al. 2014; Rummukainen 2016). The Regional Climate Model Intercomparison Project (RMIP) for Asia revealed the capacities of RCMs for simulating the Asian monsoon climate and extreme events (Fu et al. 2005). Also, to produce the improved data of regional climate projections worldwide and provide a framework for better coordination of regional climate downscaling, the World Climate Research Program (WCRP) initiated the Coodinated Regional Climate Downscaling Experiment (CORDEX) framework (Giorgi et al. 2009). The National Institute for Meteorological Sciences/Korea Meteorological Administration (NIMS/KMA) cooperating with many institutes and universities in East Asia is participating in the second phase of CORDEX-East Asia (CORDEX-EA; http://cordex-ea.climate.go.kr/) which is one of the 14 branch domains in the framework of CORDEX and utilizing beneficial DD in regional climate research (Choi and Lee 2015; Cha et al. 2016b; Kang et al. 2016; Zhou et al. 2016; Choi and Ahn 2017; Kim et al. 2017a).

In spite of the many advantages of RCM which have the added values not revealed in the climate information of GCM, the uncertainty exists in the data produced by $\mathrm{RCM}$ because it is influenced by the bias involved in the driving GCM data which is used for the Initial and Lateral Boundary Condition (IC and LBC) of RCM (Park et al. 2013; Suh and Oh 2015; Kim et al. 2017a). Furthermore, GCM Sea Surface Temperature (SST), which is used for the bottom boundary condition of RCM not coupled atmosphere and ocean, significantly affects future climate change as well as the historical climate in the data simulated by RCMs (Ashfaq et al. 2011). Thus, for more reliable RCM data, it is demanded to reduce the bias included in GCM SST as well as IC and LBC.

There were many previous studies which try to improve GCM SST bias for the diminishment of the uncertainty of RCM. First of all, Katzfey et al. (2009) described that the SST bias correction method, which eliminates climatological mean bias from monthly GCM SST using Reynolds
(1988) SST and has the observed climatological mean, considerably improves the performance on precipitation simulation of the model. However, this method showed the weakness of not simulating interannual variability well. The next thing, two quantile-mapping (QM) methods by Piani et al. (2010) and Corney et al. (2013) were found to be unsuited for SST bias correction because the trend of the underlying GCM projections is not conserved even though the improvement for the temporal variability of the SSTs. After this, it was going along previous studies for effective SST correction methods (Wang and Chen 2014; Cannon et al. 2015; Grose et al. 2015; Katzfey and Coauthors 2016; Thevakaran et al. 2016). Recently, the method in Hoffmann et al. (2016, HF16), which improve Katzfey et al. (2009)'s SST correction method, was shown that the SST correction effect can cover up to interannual variation, climate change signals, and climatological trend with the method.

Meanwhile, many studies described that SST plays an important role on precipitation phenomena in mid-latitude as well as low-latitude (Ao and Sun 2015; Dado and Takahashi 2017; Huang et al. 2012). Particularly, they described that wintertime snowfall generated by East Asian Winter Monsoon (EAWM) over East Asia is considerably related to SST. Also, previous studies in point of Numerical Weather Prediction (NWP) explained that the snowfall generated in the Korean peninsula and Japan is chiefly influenced by cold surge (or cold outbreak) which is caused by the extension of Siberian-Mongolian High (SMH) (Lee and Lee 2003; Kim et al. 2005; Cheong et al. 2006; Yamamoto and Hirose 2008; Lee and Kim 2008; Takano et al. 2008; Lee and Ryu 2010; Cha et al. 2011; Jung et al. 2012; Jeong and Park 2013; Takahashi et al. 2013; Jeong et al. 2014; Choi and Lee 2015; Kim and Jin 2016; Yeo and Ha 2017). However, there were few studies for the relationship between SST and snowfall in point of climate (observation: Fan and Tian 2013; Wang and He 2013; Takahashi and Idenaga 2013, model: Zou and Zhou 2017). So, we need to research for that in point of climate.

To investigate the impact of Bias- and VarianceCorrected SST (BCVC_SST) and DD on regional climate simulation of wintertime precipitation and snowfall over East Asia, we conducted long-term regional climate simulation for the historical climate over East Asia using RCM applied BCVC_SST and uncorrected SST. The skill of the regional climate simulation for climatological mean on precipitation and variability on snowfall in wintertime was evaluated by comparing the historical simulation and observation data. Section 2 explains the model configuration and experimental design including the SST correction method for regional climate simulations. The simulated results were analyzed and described in Section 3. Lastly, summary and concluding remarks are given in Section 4. 


\section{Model and Experimental Design}

\subsection{Regional Climate Model}

The RCM used in this study is the Hadley Centre Global Environmental Model version 3-Regional Atmosphere (HadGEM3-RA), which is based on the global atmospheric HadGEM3 of Met Office Hadley Centre (MOHC) and Unified Model (UM) version 8.2. HadGEM3-RA is a fully compressible, non-hydrostatic model (Table 1). It includes the semi-Lagrangian advection scheme with semi-implicit time integration for all prognostic variables except density. The model variables are staggered horizontally using the Arakawa-C grid and vertically using the Charney-Phillips grid (Davies et al. 2005; Wood 2013).

The physical parameterization schemes used in this study are Edwards-Slingo general 2-stream (Edwards and Slingo 1996; Cusack et al. 1998) in the radiation transfer process, Joint UK Land Environment Simulator (JULES, Best 2011; Clack 2011) in surface process, Smith (1990) in the stable layer of planetary Boundary Layer (PBL), Lock et al. (2000) in th instable layer of PBL, Gregory and Rowntree (1990) and Grant and Brown (1999) in cumulus parameterization process, the improved scheme of based on Wilson and Ballard (1999) in microphysics process, Webster et al. (2003) in gravity wave drag process. Details of the physics packages are described in Hewitt (2011) and additional model information is explained by Walters and Coauthors (2011).

\section{$60^{\circ} \mathrm{E} \quad 90^{\circ} \mathrm{E} \quad 120^{\circ} \mathrm{E} \quad 150^{\circ} \mathrm{E}$}

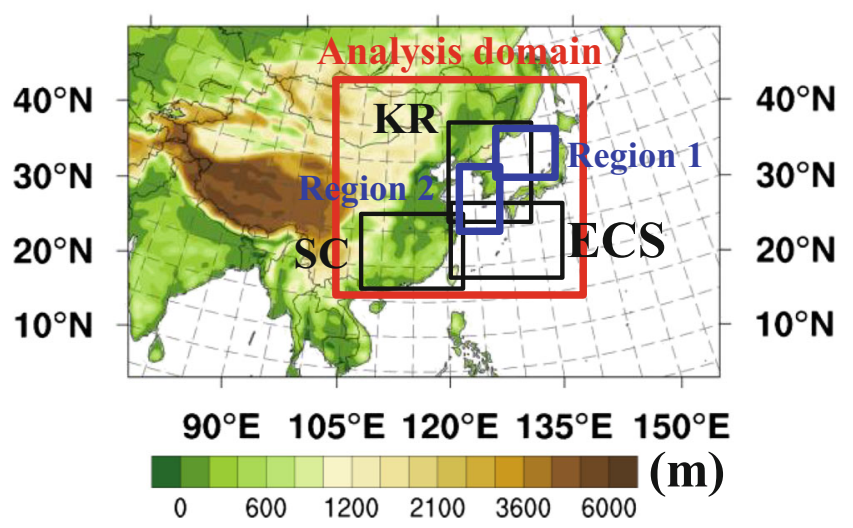

Fig. 1 Model domain and analysis subregions. East Asia: (Lat: $18 \sim 52^{\circ} \mathrm{N}$, Lon: $97 \sim 149^{\circ} \mathrm{E}$ ), KR: Korea (Lat: $32 \sim 41^{\circ} \mathrm{N}$, Lon: $121 \sim 133^{\circ} \mathrm{E}$ ), SC: South China (Lat: $23 \sim 33^{\circ} \mathrm{N}$, Lon: $107 \sim 123^{\circ} \mathrm{E}$ ), ECS: East China Sea (Lat: $22 \sim 34^{\circ} \mathrm{N}$, Lon: $122 \sim 139^{\circ} \mathrm{E}$ ), Region 1 (Lat: $36 \sim 44^{\circ} \mathrm{N}$, Lon: $128 \sim 141^{\circ} \mathrm{E}$ ), Region 2 (Lat: $29 \sim 38^{\circ} \mathrm{N}$, Lon: $121 \sim 130^{\circ} \mathrm{E}$ ). Orography $(\mathrm{m})$ is shaded

\subsection{Experimental Design}

The integration domain in this study (Fig. 1) is the second phase of the CORDEX-East Asia project; the analysis domain is the red box in Fig. 1. It was used Lambert conformal conic map projection and the information of each corner and the center points of sides at the domain were described in Table 2. This domain is included from Sri Lanka, Thailand, and Philippines to the south of Russia to north-south direction and from the west of India and Tibet Plateau to Philippines
Table 1 Model configuration of HadGEM3-RA used in this study

\begin{tabular}{ll}
\hline Contents & Description \\
\hline Domain & CORDEX-East Asia Phase 2 \\
& Cen. lat. and lon.: 61.0 ${ }^{\circ}, 2963^{\circ} \mathrm{E}$ \\
& $25 \mathrm{~km}$ (horizontal resolution) \\
& Grids: 251 (Lat.) $\times 396$ (Lon.) \\
& 63 eta levels $(\sim 41 \mathrm{~km})$ \\
Vertical layers (top) & Edwards and Slingo (1996), Cusack et al. (1999) \\
Shortwave/longwave radiation & Joint UK Land Environment Simulator (JULES) \\
Land surface model & Smith (1990), Lock et al. (2000) \\
Planetary boundary layer scheme & Gregory and Rowntree (1990), Grant and Brown (1999) \\
Cumulus parameterization scheme & Improved scheme of based on \\
Microphysics & Wilson and Ballard (1999) \\
Gravity wave drag parameterization scheme & Webster et al. (2003) \\
Lateral boundary condition & HadGEM2-AO \\
Buffer zone & 11 grid points (per each direction) \\
Spectral nudging & No \\
Integration time step & 6 mins (240 s) \\
Simulation periods & Jan. 1979 $\sim$ Dec. 2005 \\
& Spin-up time: Jan. 1979 Dec. 1980
\end{tabular}


Table 2 The information of model and analysis domain used in this study

\begin{tabular}{lll}
\hline Grid point & Model domain & Analysis domain \\
\hline TLC & $50.5^{\circ} \mathrm{N}, 51.59^{\circ} \mathrm{E}$ & $45.68^{\circ} \mathrm{N}, 98.25^{\circ} \mathrm{E}$ \\
CNB & $61.9^{\circ} \mathrm{N}, 116.7^{\circ} \mathrm{E}$ & $50.55^{\circ} \mathrm{N}, 119.35^{\circ} \mathrm{E}$ \\
TRC & $50.31^{\circ} \mathrm{N}, 181.5^{\circ} \mathrm{E}$ & $48.89^{\circ} \mathrm{N}, 148.58^{\circ} \mathrm{E}$ \\
CWB & $25.72^{\circ} \mathrm{N}, 67.11^{\circ} \mathrm{E}$ & $32.19^{\circ} \mathrm{N}, 99.21^{\circ} \mathrm{E}$ \\
CPD & $34.4^{\circ} \mathrm{N}, 116.57^{\circ} \mathrm{E}$ & $36.09^{\circ} \mathrm{N}, 121.05^{\circ} \mathrm{E}$ \\
CEB & $25.56^{\circ} \mathrm{N}, 165.94^{\circ} \mathrm{E}$ & $34.77^{\circ} \mathrm{N}, 143.95^{\circ} \mathrm{E}$ \\
BLC & $-0.1^{\circ} \mathrm{N}, 76.91^{\circ} \mathrm{E}$ & $18.63^{\circ} \mathrm{N}, 104.26^{\circ} \mathrm{E}$ \\
CSB & $6.9^{\circ} \mathrm{N}, 116.51^{\circ} \mathrm{E}$ & $21.82^{\circ} \mathrm{N}, 122.19^{\circ} \mathrm{E}$ \\
BRC & $-0.24^{\circ} \mathrm{N}, 156.08^{\circ} \mathrm{E}$ & $20.76^{\circ} \mathrm{N}, 140.74^{\circ} \mathrm{E}$ \\
\hline
\end{tabular}

*TLC (Top Left Corner), CNB (Centre point of the Northern Boundary), TRC (Top Right hand Corner), CWB (Centre point of the Western Boundary), CPD (Centre Point of the Domain), CEB (Centre point of the Eastern Boundary), BLC (Bottom Left Corner), CSB (Centre point of the Southern Boundary), BRC (Bottom Right hand Corner)

Sea and Western North Pacific to east-west direction. Particularly, it is the region reported a variety of climate phenomena that influence precipitation directly or indirectly (Zhou et al. 2016; Choi and Ahn 2017; Kim et al. 2017b).

In this study, the experiments are conducted for 27 years (1979-2005). The horizontal resolution of HadGEM3-RA is $25 \mathrm{~km}$ and it is composed of 396 grid points to the east-west direction and 251 grid points to north-south direction, and 63 levels up to $\sim 41.02 \mathrm{~km}$ vertically.

The Atmosphere-Ocean-coupled Hadley Centre Global Environmental Model version 2 (HadGEM2-AO, Baek 2013) data of $6 \mathrm{~h}$ simulated by NIMS/KMA were used as the lateral boundary conditions for HadGEM3-RA. In the atmosphere model, HadGEM2-AO has N96 $\left(1.875^{\circ} \times 1.25^{\circ}\right)$ on horizontal resolution and 38 levels up to $\sim 38 \mathrm{~km}$ vertically. The vertical levels of HadGEM2-AO were interpolated and extrapolated to those of HadGEM2-AO and the levels below tropopause of those were only used for analysis in this study. In the ocean model, HadGEM2-AO has $1^{\circ}$ on horizontal resolution and 40 levels vertically. LBC reflected in large-scale information of HadGEM2-AO forcing was not used spectral nudging technique (von Storch et al. 2000; Cha and Lee 2009; Hong and Chang 2012) and applied buffer zone composed of 11 grid.

In order to examine the RCM simulation errors related to the SST errors, two simulations were performed using the Bias- and Variance-Corrected HadGEM2-AO SST (BCVC_SST) and the uncorrected HadGEM2-AO SST (UC_SST).

The 27-year historical simulations were integrated with 6 min time-step intervals, 1979-1980 (2 years) is the spin-up period and 1981-2005 (25 years) is the analysis period. The experiments in this study are the experiment using corrected
Table 3 Model data used in this study

\begin{tabular}{ll}
\hline Model data & Description \\
\hline HG3RA_CTL & $\begin{array}{c}\text { The simulation data of HadGEM3-RA with } \\
\text { UC_SST } \\
\text { The simulation data of HadGEM3-RA with } \\
\text { BCVC_SST } \\
\text { HG3RA_BCVC } \\
\text { The forcing data used initial and boundary } \\
\text { condition of HadGEM3-RA } \\
\text { The simulation data of HadGEM3-RA with } \\
\text { HG3RA_EI }\end{array} \quad$ EISST and ERA-Interim forcing \\
\hline
\end{tabular}

*UC_SST (Uncorrected HadGEM2-AO SST) / BCVC_SST (Bias- and Variance-corrected HadGEM2-AO SST) / EI_SST (ERA-Interim SST)

SST (HG3RA_BCVC) and uncorrected SST (HG3RA_CTL). To compare the results between GCM and RCM, HadGEM2AO data (HG2AO) and the data of HG3RA_EI, which is the experiment using Interim European Centre for Medium-range Weather Forecast Re-Analysis (ERA-Interim, Dee 2011) as LBC, as well as two experiments were analyzed (Table 3). SST correction method was specifically explained in the next part.

Observational data from the $2.5^{\circ}$-resolution Global Precipitation Climatology Project (GPCP version 2.2, Adler 2003) and the $0.25^{\circ}$-resolution Asian Precipitation-Highly Resolved Observational Data Integration Towards Evaluation of Water Resource (APHRODITE version 1101R1, Yatagai et al. 2012) are used to evaluate the simulated precipitation. In addition, the $0.25^{\circ}$-resolution SST, $1.5 \mathrm{~m}$ temperature, zonal $(\mathrm{U})$ and meridional $(\mathrm{V})$ wind at 1000 and $850 \mathrm{hPa}$, specific humidity (q) at $850 \mathrm{hPa}$, sea level pressures (SLP), and surface latent (SLHF) and sensible (SSHF) heat fluxes of the ERA-Interim analysis are used to evaluate the corresponding model fields. Moisture Horizontal Advection (MHA, Banacos and Schultz 2005) defined as $-u \frac{\partial q}{\partial x}-v \frac{\partial q}{\partial y}$ is also calculated from $\mathrm{U}, \mathrm{V}$, and $\mathrm{q}$.

To examine the relationship between SST and snowfall, we used the daily snowfall data observed at the 45 ground meteorological sites, the Automated Synoptic Observing System (ASOS), operated by the KMA from the National Climate Data Service System (NCDSS, sts.kma.go.kr).

\subsection{SST Correction Method}

The GCM SST correction method used in this study is based on HF16 using SST data collected by NIMS (Martin 2011). SST correction process needs GCM SST which is correction SST and observation or reanalysis SST which is reference SST.

In HF16, Australian Community Climate and Earth System Simulator (ACCESS1.0, Bi 2013) SST developed by Commonwealth Scientific and Industrial Research 
Organization (CSIRO) and Bureau of Meteorology in Australia (BOM) was used with correction SST. Optimal Interpolated SST (OISST version 2.2, Reynolds et al. 2007; Reynolds 2009) of National Oceanic and Atmospheric Administration (NOAA) and Hadley Centre SST (HadISST version 1, Rayner et al. 2003) was used with reference SST. In HF16, corrected SST applied in a conformal-cubic atmospheric model (CCAM, McGregor 1996, 2005a, 2005b; McGregor and Dix 2008).

In this study, we used the HadGEM2-AO SST with GCM SST and ERA-Interim SST (EI_SST) with the reference SST. we applied correction SST in HadGEM3-RA and integrated historical simulation experiments. By using EI_SST, we could skip the sea ice calculation process which was conducted in the SST correction process of HF16 and occurred by missing data of SST.

Looking SST correction method described in HF16 closer, like Eq. (1), Correction Factor (CF) is calculated to the ratio of standard deviation between observation $\left(S S T_{O B S}\right)$ and model $\left(S S T_{G C M}\right)$ SST.

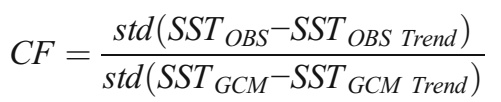

Here, the trend of observation and model for 35 years are Eqs. (2) and (3) respectively. Model parameters $\left(a_{O B S}, b_{O B S}\right.$, $a_{G C M}, b_{G C M}$ ) are defined by linear regression of Eqs. (2) and (3).

$$
\begin{aligned}
& S S T_{O B S \text { Trend }}=b_{O B S} \cdot x+a_{O B S} \\
& S S T_{G C M \text { Trend }}=b_{G C M} \cdot x+a_{G C M}
\end{aligned}
$$

In order to apply time series of $S S T_{G C M}$ to CF, like Eq. (4), anomaly of each monthly $S S T_{G C M}$ is calculated for all period. Here, $S S T_{G C M ~ R T}$ is SST of the last month in trend line calculated to backward running trend for 30 years each month.

$S S T_{G C M ~ A N O M}=S S T_{G C M}+S S T_{G C M R T}$

Variance-corrected SST $\left(S S T_{G C M} V C, V C \_S S T\right)$ is calculated like Eq. (5) using CF, $S S T_{G C M} A N O M, S S T_{G C M ~ R T}$ calculated from Eqs. (1)-(4).

$S S T_{G C M V C}=C F \cdot S S T_{G C M A N O M}+S S T_{G C M R T}$

Next, Bias- and Variance-corrected SST ( $S S T_{G C M ~ B C V C}$, $B C V C_{-} S S T$ ) is calculated like Eq. (7) using Eq. (5) for VC_SST and Eq. (6) for BIAS which is the difference of recent climatology-mean between VC_SST and observation SST.

$$
\begin{aligned}
& B I A S=\overline{S S T_{G C M V C}}+\overline{S S T_{O B S}} \\
& S S T_{G C M B C V C}=S S T_{G C M V C}-B I A S
\end{aligned}
$$

Meanwhile, bias-corrected SST $\left(S S T_{G C M B C}, B C \_S S T\right)$ is calculated by Eqs. (8) and (9) that is SST correction method in Katzfey et al. (2009).

$B I A S_{B C}=\overline{S S T_{G C M}}+\overline{S S T_{O B S}}$

$S S T_{G C M B C}=S S T_{G C M}-B I A S_{B C}$

Here, $B I A S_{B C}$ is the difference of recent climatology-mean using model SST $\left(S S T_{G C M}\right)$ instead of VC_SST $\left(S S T_{G C M} V C\right)$.

Figure 2 shows the spatial distributions of SST and the difference between SSTs during January averaged for 1981 2005 (25 years) using EI_SST (the observed SST), UC_SST (the uncorrected HadGEM2-AO SST), BC_SST (the Bias-corrected HadGEM2-AO SST), and BCVC_SST (the Bias- and Variance-corrected HadGEM2-AO SST) calculated by the formula (1)-(9). The spatial distribution of EI_SST describes that it is low in low latitude, high in high latitude, and it is relatively high in the sea from Okinawa to the west of Kyushu, which is analyzed to Kuroshio current (Fig. 2a). The results using UC_SST were different from those of EI_SST in the sea shown Kuroshio current and East and Yellow Sea (Fig. 2b). The distribution of the difference between each SST and EI_SST described that the bias with BCVC_SST (the absolute bias averaged over analysis domain: $0.73 \mathrm{~K}$ ) decreased more than that with UC_SST (the absolute bias averaged over analysis domain: $1.49 \overline{\mathrm{K}}$ ), particularly, than that with BC_SST (the absolute bias averaged over analysis domain: $1.02 \mathrm{~K}$ ) (Fig. 2e-g). It explains that SST correction chiefly made UC_SST cool in a great deal of sea including the Kuroshio Current and East and Yellow Sea, but the parts of coastline in middle latitude and the western North Pacific. Therefore, the upper results know that Biasand Variance-corrected SST method is significantly meaningful in January.

\section{Results}

\subsection{Assessment of Precipitation Simulation}

In this section, we describe the impact of the corrected SST on the climatological mean precipitation and snowfall by comparing the results from the two RCM simulations and the HG2AO data against the observation. Figure 3 shows the 25-yr DJF mean precipitation and the differences between the model data and the observation. The difference in the spatial distribution between GPCP and APHRODITE in Korea, Japan, and Maritime Territory (Primorsky Kray) is less than $2 \mathrm{~mm} \mathrm{~d}^{-1}$ (Kim et al. 2015). It is the negligible value that comes from the difference of horizontal resolution, data assimilation, and raw data between them (Andermann et al. 2011). The spatial pattern of precipitation in 
Fig. 2 Spatial distributions of SST (K) during January averaged for 1981 2005 (25 years): (a) ERA-Interim SST (EI_SST), (b) uncorrected GCM SST (UC SST), (c) bias-corrected GCM SST (BC SST), (d) bias- and variance-corrected GCM SST (BCVC_SST). Spatial distribution of the difference between (e) panel (a) and (b), (f) panel (a) and (c), and (g) panel (a) and (d). The results of $(\mathbf{a}) \sim(\mathbf{g})$ are statistically significant values at 5\% significance level of t-test
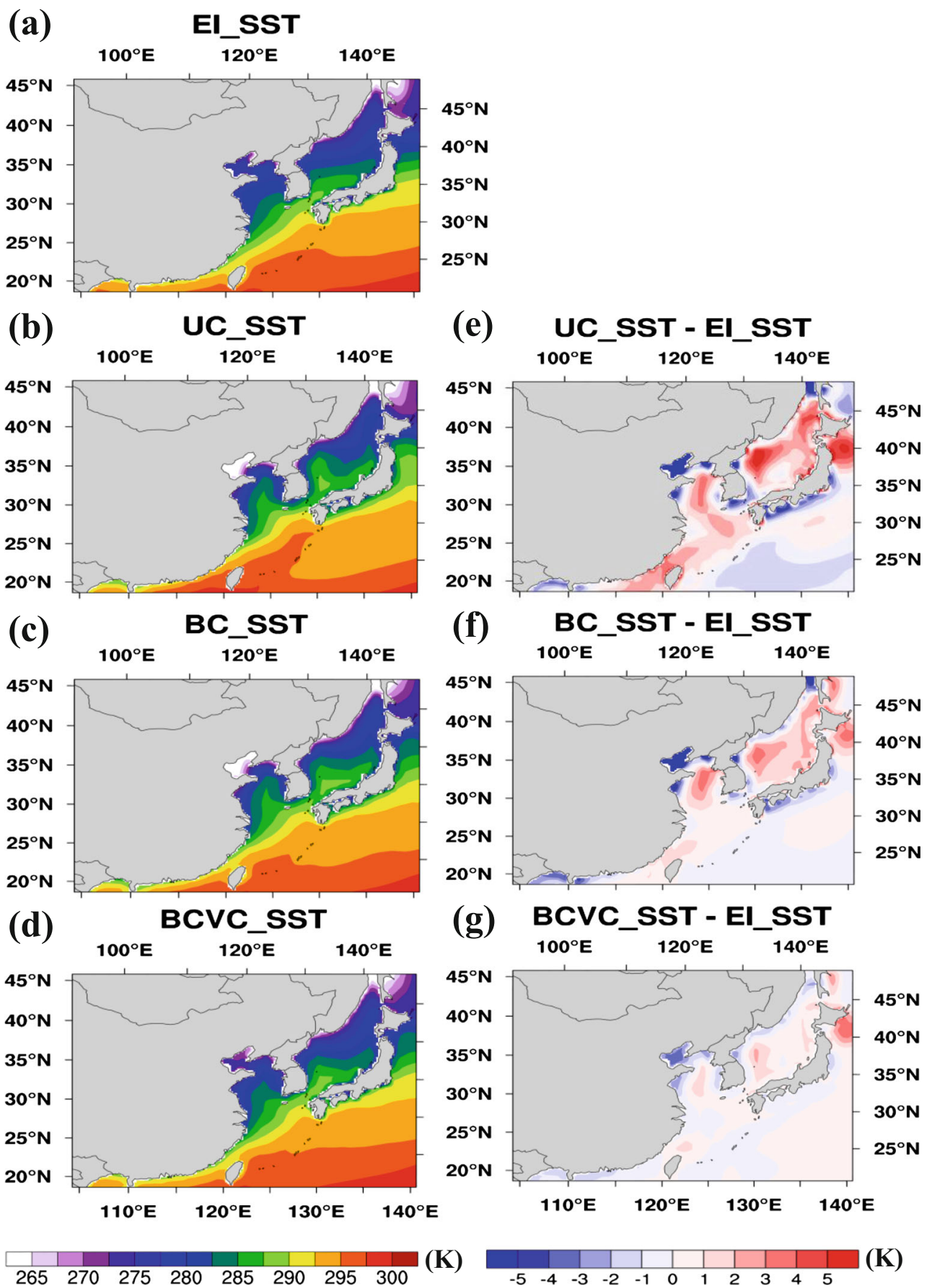

(K)

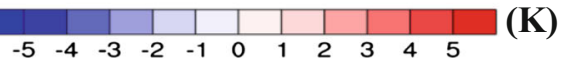

HG3RA_BCVC, HG3RA_CTL, and HG2AO over South China, Korea, Japan, East China Sea, Yellow Sea, East Sea, and Sea of Japan side is comparable to that of the observation (Fig. 3a-j). However, the strength of that in model data is shown the differences with the observation, particularly, in ocean $\left(0.62-1.63 \mathrm{~mm} \mathrm{~d}^{-1}\right)$ than land $\left(0.03-0.32 \mathrm{~mm} \mathrm{~d}^{-1}\right)$ (Fig. 3e-k). They are improved by applying corrected SST as well as using RCM instead of GCM over South China and Japan in land and East China Sea, East Sea, and Sea of Japan side in ocean (Fig. 3e-1). Meanwhile, the difference with GPCP over the Honshu of Japan is shown more increase in the result using RCM than that using GCM, contrary to that with APHRODITE. It is because GPCP having low-resolution does not well describe the precipitation of model having highresolution such as APHRODITE. The increase of horizontal resolution can display more realistic orography with smallscale precipitation (Gampe and Ludwig 2017). In other words, GPCP is deficient in detailed precipitation display over the Honshu of Japan having comparatively steep terrain and complex coastal line. 
(a) GPCP

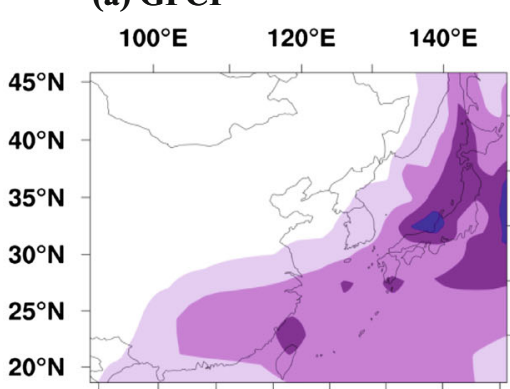

(d) HG3RA_BCVC

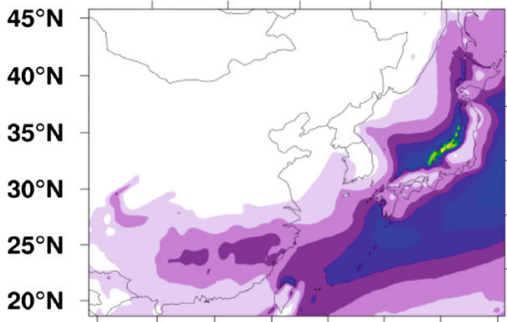

(g) HG3RA_CTL

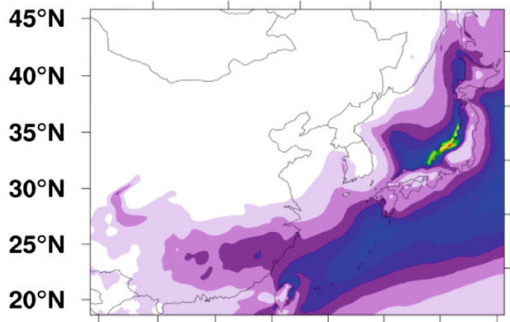

(j) HG2AO

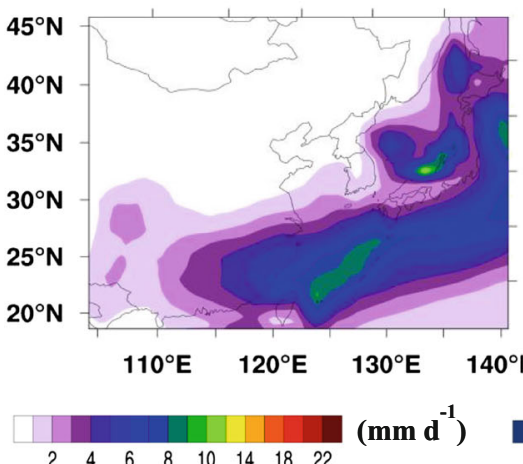

(b) APHRODITE

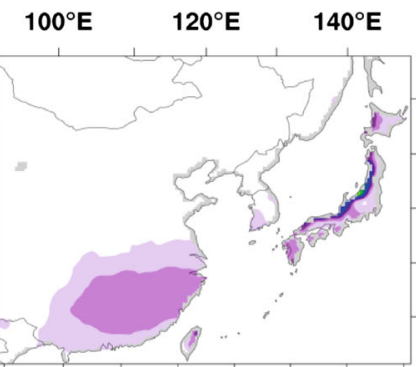

(e) HG3RA_BCVC - GPCP

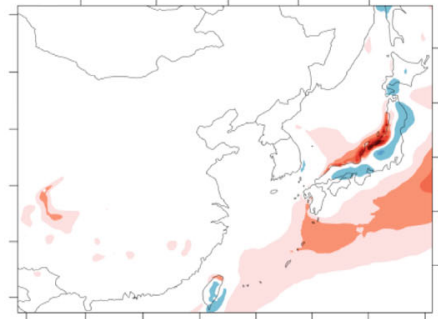

(h) HG3RA_CTL - GPCP

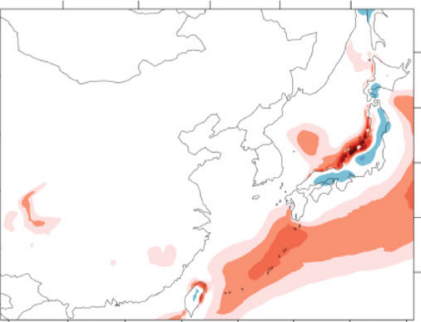

(k) HG2AO - GPCP

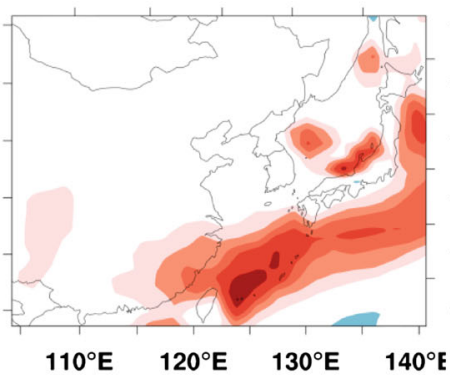

(c) GPCP - APHRODITE

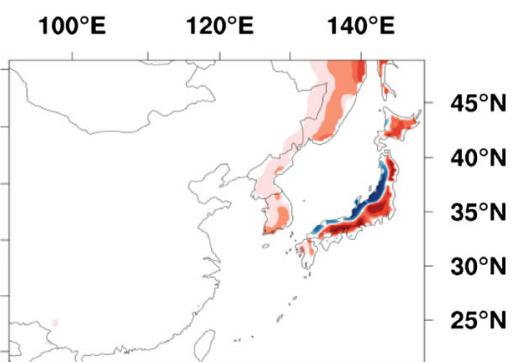

(f) HG3RA BCVC - APHRODITE

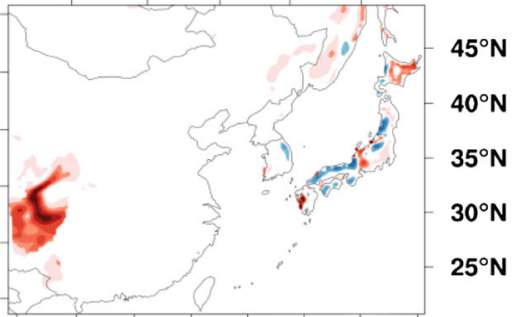

(i) HG3RA_CTL - APHRODITE

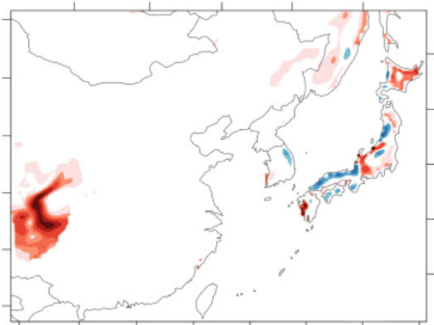

(l) HG2AO - APHRODITE

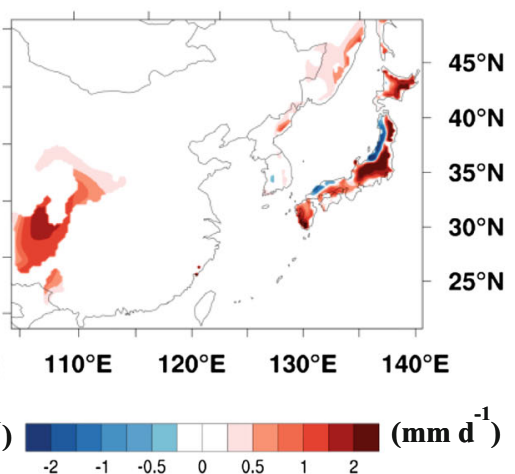

Fig. 3 Spatial distribution of DJF mean precipitation $\left(\mathrm{mm} \mathrm{d}^{-1}\right)$ over East Asia region during 1981 2005. First row: (left) GPCP, (center) APHRODITE, and (right) differences between GPCP and APHRODITE. Second to fourth row: (left) simulated precipitation, (center) bias of simulated precipitation from GPCP, and (right) bias of simulated precipitation from APHRODITE. The results of simulated precipitation from second to fourth row are HG3RA_BCVC, HG3RA_CTL, and $\mathrm{HG} 2 \mathrm{AO}$, respectively. The left, center, and right color bar are for the left, center, and right column respectively. The results of the difference are the significant value within the variation range of observation data
Figure 4 shows the statistics of the simulated DJF precipitation for the period 1981-2005. Figures $4 \mathrm{a}$ and $\mathrm{b}$ are the result of Fig. 3f, i, and 1 for APHRODITE and of Fig. 3e, h, and k for GPCP, respectively. Figure 4a describes the remarkable effect of dynamical downscaling using RCM with blue and green circles which is closer to zero than red circles in the value of Root Mean Square Error (RMSE) and bias. But, the influence of SST correction is weak and the difference between circles in the value of Pattern Correlation Coefficients (PCC) is low. Meanwhile, Fig. 4b explains the accepted improvement of SST correction over the seas in the region with the result of blue circles as well as the effect of dynamical downscaling (red and green mark). And it shows a small improvement in the value of PCC. Consequently, the cooling of SST by the SST correction 
(a) Land

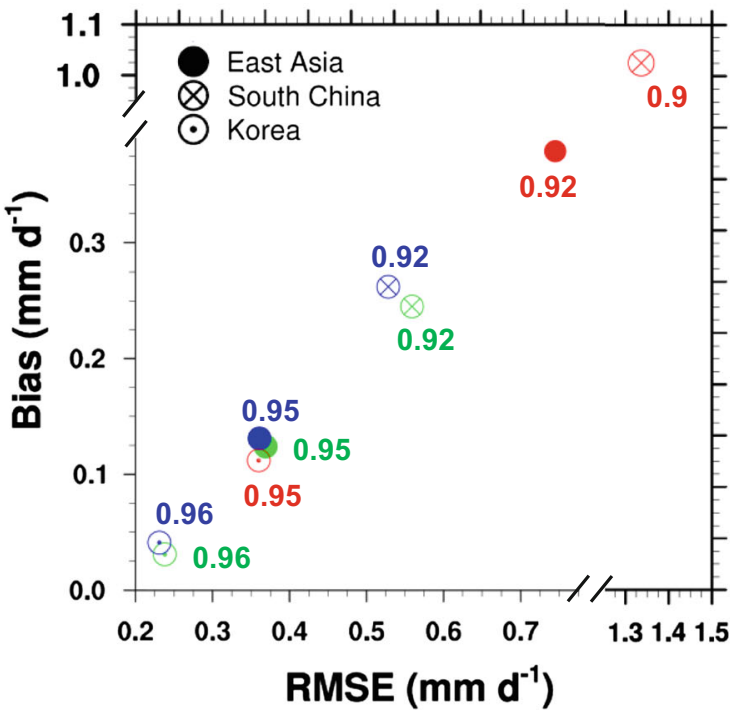

Fig. 4 BCR (Bias, Pattern Correlation Coefficients (PCC), RMSE) diagram for DJF mean precipitation $\left(\mathrm{mm} \mathrm{d}^{-1}\right)$ over (a) land and (b) ocean of East Asia during the 25-yr period (1981 2005). East Asia (Lat: $18 \sim 52^{\circ} \mathrm{N}$, Lon: $97 \sim 149^{\circ} \mathrm{E}$ ): filled circle (land) and 6 point star (ocean), Korea (Lat: $32 \sim 41^{\circ} \mathrm{N}$, Lon: $121 \sim 133^{\circ} \mathrm{E}$ ): dotted circle (land) and hollow square (ocean), South China (Lat: $23 \sim 33^{\circ} \mathrm{N}$, Lon:

decreases overestimated precipitation of HadGEM3-RA over the seas in East Asia included that around Korea.

Additionally, we investigated the effect of dynamical downscaling and SST correction at some subregions. The intraseasonal variation of the DJF precipitation over analysis domain and five subregions of Fig. 1 in APHRODITE or GPCP (thick and black), HG3RA BCVC (thick and blue), HG3RA_CTL (green), and HG2AO (red) for the period 1981 2005 period are shown in Fig. 5. The results compared with APHRODITE in land describe the decrease of the overestimation in experiments using RCM, particularly, that in South China (Fig. 5a-e). Over the ocean in East Asia, the improvement (the difference between blue and black line: $0.02-1.25 \mathrm{~mm} \mathrm{~d}^{-1}$ ) of precipitation by SST correction is shown as well as that (the difference between red and black line: $0.42-3.01 \mathrm{~mm} \mathrm{~d}^{-1}$ ) by dynamical downscaling (Fig. 5bh). Figure 5 shows that the effects of the SST correction on the RCM precipitation simulation is small over the land surface and the coastal seas such as the Yellow Sea but are notable over open seas (the difference between green and blue line: $0.09-0.43 \mathrm{~mm} \mathrm{~d}^{-1}$ ). It is also shown that the improvements in precipitation by the use of corrected SST for open oceans (the difference between red and green line: $0.6-1.78 \mathrm{~mm} \mathrm{~d}^{-1}$ ) is comparable to that achieved by dynamical downscaling.

As well as the improvement of the mean bias in the analysis of the intraseasonal variability of DJF, it is important to analyze and confirm that of standard deviation bias on interannual variability. we calculated standard deviation (STD) of models and observation at 3 land and 5 ocean subregions for (b) Ocean

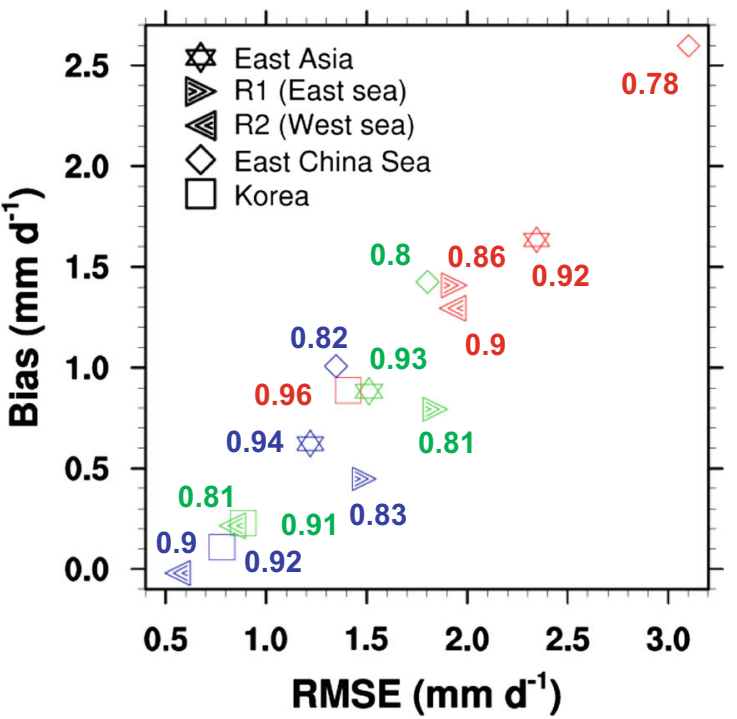

$107 \sim 123^{\circ} \mathrm{E}$ ): cross circle (land), East sea (Lat: $36 \sim 44^{\circ} \mathrm{N}$, Lon: $128 \sim 141^{\circ} \mathrm{E}$ ): filled right triangle (ocean), West sea (Lat: $29 \sim 38^{\circ} \mathrm{N}$, Lon: $121 \sim 130^{\circ} \mathrm{E}$ ): filled left triangle (ocean), East China sea (Lat: $22 \sim 34^{\circ} \mathrm{N}$, Lon: $122 \sim 139^{\circ} \mathrm{E}$ ): diamond (ocean). Blue, green, and red results are HG3RA_BCVC, HG3RA_CTL, and HG2AO, respectively. X-axis, Yaxis, and number are RMSE, Bias, $\mathrm{PCC}$, respectively

December, January, February, and DJF. Observation data shows greater variation at small region (STD: 0.07-0.83) than that at large region (STD: 0.07-0.42), in ocean (STD: 0.070.83 ) than that in land (STD: 0.07-0.72), in high latitude (STD: 0.14-0.83) than in low latitude (STD: 0.07-0.72) comparatively. Models data describe a variety of variability according to respective subregions and periods. However, the effect of the dynamical downscaling and bias correction shows the value having bold character and having a star in Table 4 and the effect of the dynamical downscaling is larger than that of bias correction relatively.

\subsection{Relationship between SST and Snowfall}

In this section, we explore the impact of corrected SST on the viewpoint of inter-annual variation in the correlation relationship between SST and snowfall by comparing the results from the three RCM simulations and the HG2AO data against the observed data. Figure 6 shows the spatial patterns of correlation coefficient which has a $90 \%$ significance level between snowfall averaged over South Korea and SST anomaly of each grid point in the ocean of East Asia for 1981-2005 (25 years) January. It describes that the negative correlation relationship of the result of HG3RA BCVC experiment is more similar to that of observation data than that of HG3RA EI, HG2AO, and HG3RA CTL in region 1 and 2. This result is different from the positive value in previous studies in point of NWP is supported by the result in Takahashi and Idenaga (2013). They showed the negative correlation relationship between snowfall 
Fig. 5 The time series of DJF precipitation ( $\mathrm{mm} \mathrm{d}^{-1}$, monthly averages) over analysis domain (East Asia) and five subregions of Fig. 1 in APHRODITE or GPCP (thick and black), HG3RA BCVC (thick and blue), HG̈3RA CTL (green), and HG2AO (red) for the period 1981 2005. The error bars on APHRODITE or GPCP data points correspond to the 1-sigma standard deviation (a) East Asia (land)

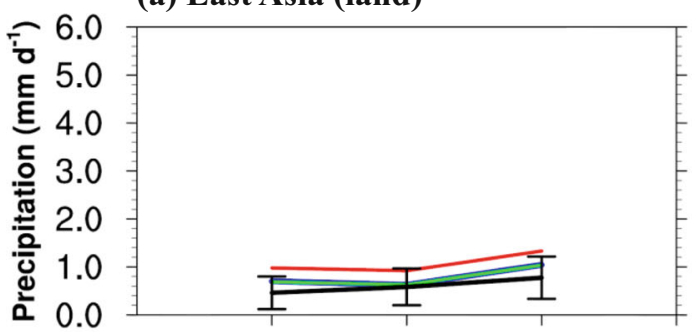

(c) Korea (land)

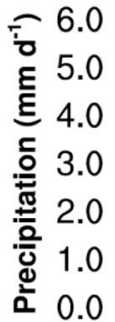

(b) East Asia (ocean)

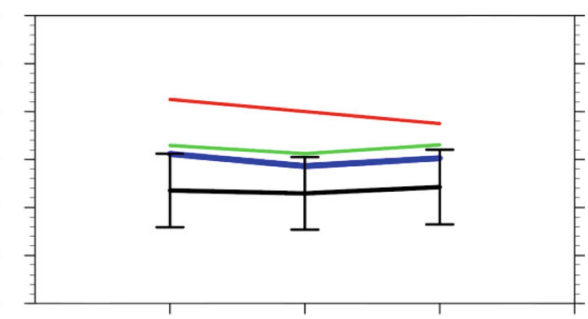

(d) Korea (ocean)

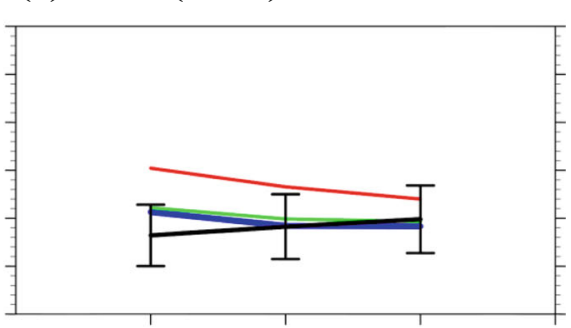

(f) East China Sea (ocean)

(e) South China (land)

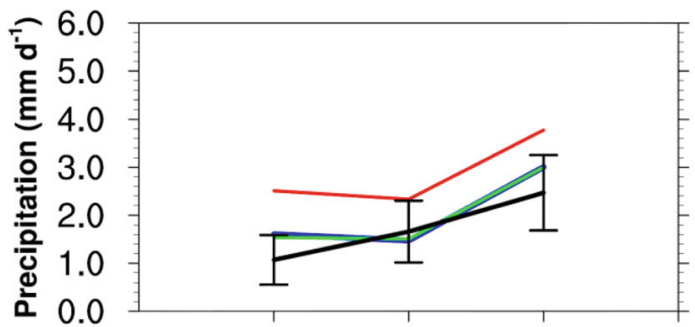

(g) Yellow Sea (ocean)

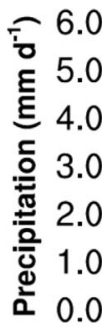

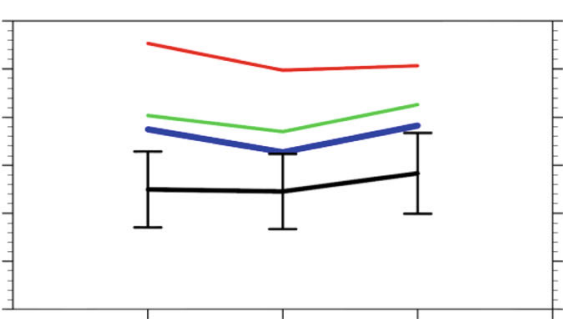

(h) East Sea (ocean)

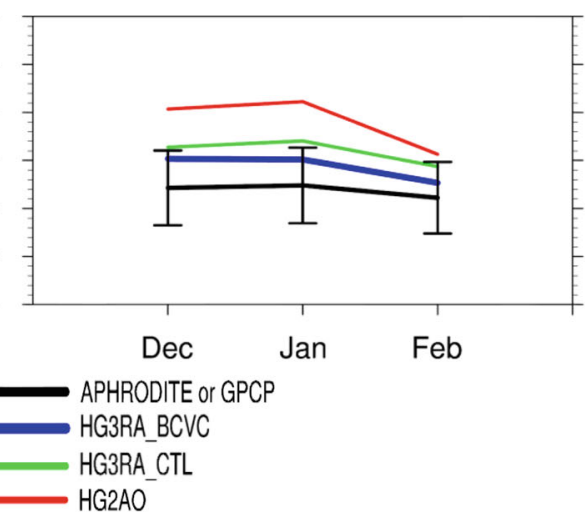

observed at 76 Automated Meteorological Data Acquisition System (AMeDAS) stations and several SSTs influenced by cold surges on 15-day and 1-month mean values. Meanwhile, the result of HG3RA_EI experiment which is simulated by RCM, not GCM shows negative values in region 1. In comparison between the result of it and HG2AO, we can know the improvement of the correlation relationship by dynamical downscaling using RCM (Fig. 6b and c). Also, in comparison between the result of HG3RA_BCVC and HG3RA_CTL, which is shown the weak and negative value and has the bias in HG2AO forcing, we can know the impact of SST correction (Fig. 6d and e).
To understand the negative correlation relationship shown in Fig. 6 in more detail, we analyzed Fig. 7 which is time series between the snowfall anomaly averaged over South Korea and the SST anomaly over East Sea (region 1 in Fig. 6) for 1981-2005 (25 years) January. Compared to the result of observation data shown negative correlation relationship $(-0.361)$ in 1983 and the mid-1990s (Fig. 7a), the results of HG3RA_EI experiment (-0.575), and HG3RA_CTL experiment $(-0.216)$ maintain negative correlation coefficient $(\mathrm{CC})$ relatively well but break this relationship since early 1990s, particularly, that of HG2AO data (0.182) has positive CC. Eventually, CC between SST and snowfall anomaly of 
Table 4 The interannual standard deviation of observation (OBS), HG3RA_BCVC, HG3RA_CTL, and HG2AO data over 8 regions for December, January, February, and DJF in Fig. 5

\begin{tabular}{|c|c|c|c|c|c|c|c|c|c|}
\hline East Asia (land) & Dec & Jan & Feb & DJF & East Asia (ocean) & Dec & Jan & Feb & DJF \\
\hline OBS & 0.190 & 0.188 & 0.271 & 0.158 & OBS & 0.418 & 0.399 & 0.711 & 0.066 \\
\hline HG3RA_BCVC & 0.224 & 0.149 & $0.249 *$ & 0.222 & HG3RA_BCVC & 1.066 & $0.411 *$ & 0.534 & 0.129 \\
\hline HG3RA_CTL & 0.172 & 0.162 & 0.236 & 0.220 & HG3RA_CTL & 0.519 & 0.488 & 0.555 & 0.103 \\
\hline $\mathrm{HG} 2 \mathrm{AO}$ & 0.194 & 0.171 & 0.236 & 0.222 & $\mathrm{HG} 2 \mathrm{AO}$ & 0.536 & 0.506 & 0.606 & 0.253 \\
\hline Korea (land) & Dec & Jan & Feb & DJF & Korea (ocean) & Dec & Jan & Feb & DJF \\
\hline OBS & 0.202 & 0.239 & 0.278 & 0.071 & OBS & 0.423 & 0.442 & 0.628 & 0.168 \\
\hline HG3RA_BCVC & 0.265 & $0.219 *$ & 0.315 & 0.099 & HG3RA_BCVC & 0.526 & $0.462 *$ & $0.555^{*}$ & $0.168^{*}$ \\
\hline HG3RA_CTL & 0.257 & 0.221 & 0.288 & 0.103 & HG3RA_CTL & 0.484 & 0.518 & 0.553 & 0.151 \\
\hline $\mathrm{HG} 2 \mathrm{AO}$ & 0.260 & 0.358 & 0.416 & 0.060 & $\mathrm{HG} 2 \mathrm{AO}$ & 0.577 & 0.599 & 0.837 & 0.324 \\
\hline South China (land) & Dec & Jan & Feb & DJF & East China Sea (ocean) & Dec & Jan & Feb & DJF \\
\hline OBS & 0.720 & 0.679 & 1.032 & 0.703 & OBS & 0.702 & 0.696 & 1.144 & 0.207 \\
\hline HG3RA_BCVC & 0.809 & 0.629 & $0.926^{*}$ & 0.848 & HG3RA_BCVC & 1.780 & $0.690 *$ & 0.866 & 0.300 \\
\hline HG3RA_CTL & 0.600 & 0.701 & 0.877 & 0.853 & HG3RA_CTL & 0.909 & 0.819 & 0.881 & 0.283 \\
\hline $\mathrm{HG} 2 \mathrm{AO}$ & 0.769 & 0.669 & 0.779 & 0.786 & $\mathrm{HG} 2 \mathrm{AO}$ & 1.080 & 0.760 & 1.065 & 0.299 \\
\hline Yellow Sea (ocean) & Dec & Jan & Feb & DJF & East Sea (ocean) & Dec & Jan & Feb & DJF \\
\hline OBS & 0.625 & 0.681 & 0.833 & 0.322 & OBS & 0.422 & 0.439 & 0.551 & 0.136 \\
\hline HG3RA_BCVC & 0.883 & $0.589 *$ & $0.854 *$ & $0.291 *$ & HG3RA_BCVC & $0.601 *$ & $0.666^{*}$ & 0.402 & 0.285 \\
\hline HG3RA_CTL & 0.653 & 0.711 & 0.969 & 0.234 & HG3RA_CTL & 0.662 & 0.843 & 0.502 & 0.278 \\
\hline $\mathrm{HG} 2 \mathrm{AO}$ & 0.894 & 0.747 & 1.141 & 0.416 & $\mathrm{HG} 2 \mathrm{AO}$ & 0.705 & 0.897 & 0.652 & 0.593 \\
\hline
\end{tabular}

HG3RA_EI experiment, HG2AO data, and HG3RA_CTL experiment in region1 (region2) for 1981-2005 shows the value of $-0.239(-0.113), 0.148(-0.141)$, and -0.045 $(-0.059)$ (Fig. 7b, c, and d). Contrastively, the result of HG3RA_BCVC has large negative CC of $-0.329(-0.266)$ and is similar to that of observation data having that of -0.305 (-0.444) in region1 (region2) (Fig. 7a and e). In comparison with the results of SST anomaly, that of HG3RA_EI is similar to that of observation because of using EI_SST and their CC is nearly close to one. However, that of HG3RA_CTL (CC: -0.335) using UC_SST, which is SST produced by HG2AO experiment (CC: -0.039 ), does show the dissimilar result with that of HG3RA_EI, which uses EI_SST, and observation. Even though the result of HG3RA_BCVC applying bias correction with EI_SST makes effort to improve this drawback (Fig. 7e), it has 3-6 year time lag shown in that of HG2AO experiment as well as the magnitude of SST anomaly (Fig. 7a, c, and e). This time lag shows that the bias correction applied EI_SST having a 1-month time scale in UC_SST having a 6-hour time scale does not large influence such as the magnitude which can change the sign. That in region 2 (Yellow Sea) is similar to that in region 1 (East Sea) but has 1-6 year time lag (not shown). They indicate SST of HG3RA_BCVC embedded SST bias of HG2AO and the limitation of SST bias- and variance-correction. In comparison with the result of the snowfall anomaly, that of the respective experiment is different from that of observation data with the value less than $0.309 \mathrm{CC}$. This is because snowfall anomaly is produced under the reflection of dynamics and many physical processes of the model. Meanwhile, that of HG3RA_BCVC is similar to that of HG3RA_CTL and they have the value of $0.892 \mathrm{CC}$ even if the difference of two experiments is only UC_SST and BCVC_SST (Fig. 7d and e). Also, that of HG3RA_EI is significantly different from that of observation even though the similar SST anomaly (Fig. 7a and b). The snowfall anomaly of each data in region 2 has a wider range of variation than that in region 1 (not shown). As a result, snowfall anomaly is more influenced by other factors than SST anomaly unlike rainfall at low latitude more affected by SST anomaly. We could confirm it is atmospheric field reflected dynamics and physics of model (described in detail in the next paragraphs for Fig. 8 and 9).

To investigate the influence of SST correction and atmospheric field on snowfall in the negative correlation relationship between SST and snowfall anomaly, we analyzed Fig. 8 and 9 which are the composite maps of the difference between case 1 (the years when relatively lower SST anomaly and higher snowfall anomaly) and case 2 (the years when relatively higher SST anomaly and lower snowfall anomaly) in Fig. $7 \mathrm{a}$ and e of each variable over East Asia region. In the selection of case 1 and 2, we found all of case 1 and 2, calculated the negative $\mathrm{CC}$, and differentiated the cases having the high value to analyze more clearly. Here, the number of case 1 and 2 of observation data and HG3RA_BCVC experiment is the 
Fig. 6 Spatial patterns of the correlation coefficient between snowfall averaged over South Korea and SST anomaly of each grid point in ocean of East Asia for 1981-2005 (25 years) January: (a) 45 KMA stations snowfall and ERA-Interim SST, (b) HG3RA_EI experiment, (c) HG2AO data, (d) HG3RA_CTL experiment, and (e) HG3RA $\mathrm{BCVC}$ experiment. Correlation coefficients with a local significance level of $90 \%$ are plotted, as determined using Student s t-test (a) Observation

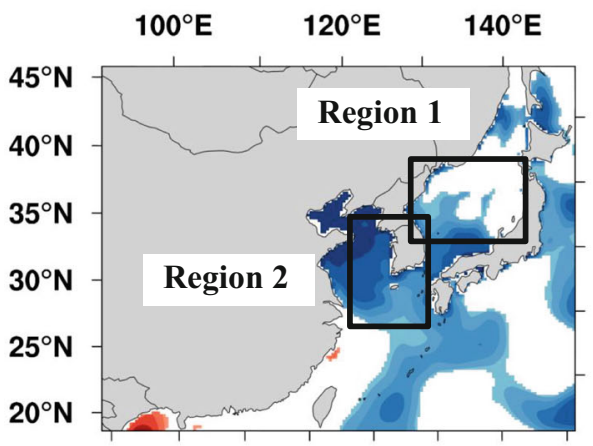

(c) HG2AO
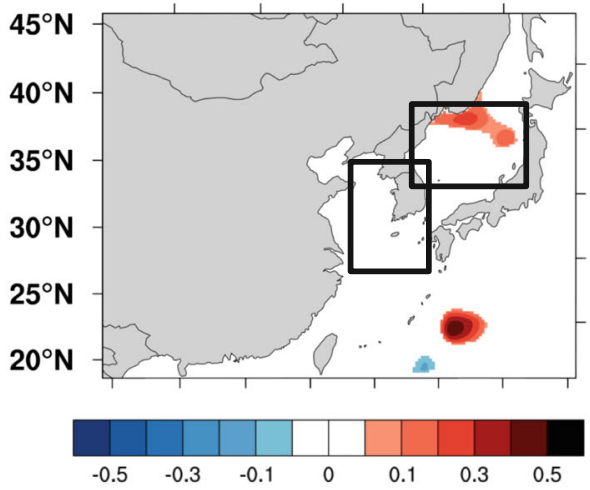

(b) HG3RA_EI

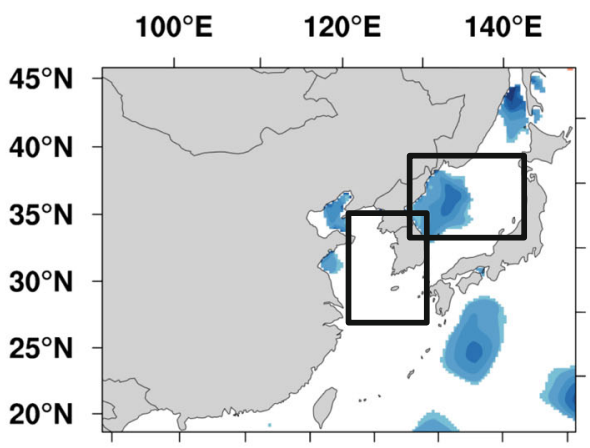

(d) HG3RA_CTL

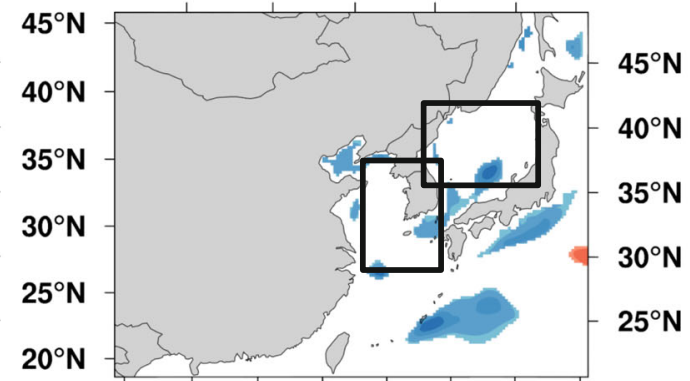

(e) HG3RA_BCVC

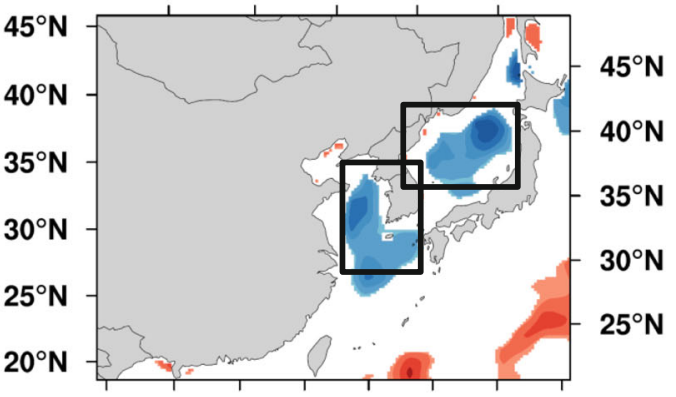

same. In Fig. 8, the results of observation data (Fig. 8a-f) in region 1 and 2 show the difference in the spatial distribution of composite map of SST and Surface Sensible and Latent Heat Flux (SSHF and SLHF). Positive values shown weakly in region 1 and 2 of SST (Fig. 8a and d) appear at the results of SSHF and SLHF (Fig. 8b, c, e, and f), particularly those of SLHF in region 2 (Fig. 8f). It also shows in the results of HG3RA_BCVC near the coastline such as observation data but positive values of HG3RA_BCVC in region 1 and 2 are located in lower latitude than observation data. They are different from the results in previous studies in point of NWP (in 4th paragraph of Section 1). So we can think that the source of SSHF and SLHF besides SST exists in the point of climate, not NWP.

Figure 9 explains atmospheric fields are other sources of SSHF and SLHF. The observation data in Fig. 9 shows that in accordance with the distribution of Sea Level Pressure (SLP), northeasterly wind in region 1 (Fig. 9a) and north or northwesterly wind in region 2 (Fig. 9d) make cold air (Fig. 9b and e) moved to the Korean Peninsula. The distribution of Moisture Horizontal Advection (MHA, Banacos and Schultz 2005) defined as $-\mathbf{u} \frac{\partial \mathbf{q}}{\partial \mathbf{x}}-\mathbf{v} \frac{\partial \mathbf{q}}{\partial \mathbf{y}}$ describes that the dry air (blue shaded area) is changed to the moist air (red shaded area) in region 1 (Fig. 9c) and the less moist air (light red shaded area) is done to the more moist air (dark red shaded area) in region 2 (Fig. 9f) with the approach at the Korean Peninsula. So, unlike the composite map of SST, those of SSHF and SLHF show positive value (red shaded area) with meeting Yellow sea and moving to the Korean Peninsula. In conclusion, despite relatively low SST, relatively strong and cold wind helps snowfall in the Korean Peninsula increased (case 1) and even though relatively high SST, that is reversely decreased by relatively weak wind (case 2). As well as observation data, the results of HG3RA BCVC, which is comparatively the most similar with the negative correlation relationship between SST and snowfall anomaly in observation data, explain that snowfall in the Korean 
(a) Observation

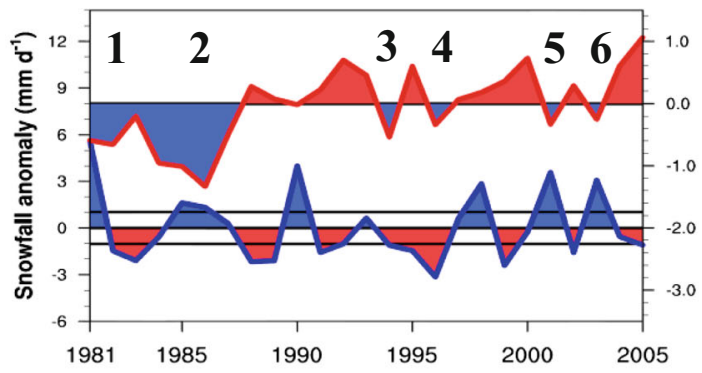

(c) HG2AO
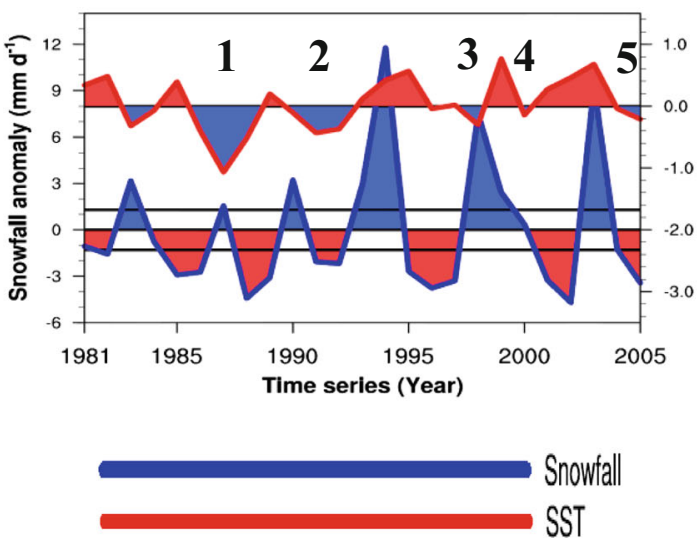

Fig. 7 Time series between snowfall anomaly averaged over South Korea and SST anomaly done over East Sea (region 1 in Fig. 6) for 1981-2005 (25 years) January: (a) 45 KMA stations snowfall and ERA-Interim SST, (b) HG3RA_EI experiment, (c) HG2AO data, (d) HG3RA_CTL experiment, and (e) HG3RA_BCVC experiment. Snowfall and SST anomalies

Peninsula are governed by atmospheric fields and SST around it affects the snowfall as the source of it (Fig. 9g-1). But, in compliance with the difference with the atmospheric fields of observation data, the moist air (red shaded area) in region 1 exists in lower latitude than the result of observation data (Fig. 9c and i) and the more moist air (dark red shaded area) in region 2 does in the location moving to the northwest than that (Fig. 9f and 1). Thus, the improvement of atmospheric fields, particularly LBC related to them, is requested in this study.

\section{Summary and Concluding Remarks}

In this study, regional climate simulation was dynamically downscaled using the HadGEM3-RA with a $25 \mathrm{~km}$ horizontal resolution forced by LBC of HadGEM2-AO and ERAInterim. To decrease the bias of HadGEM2-AO SST, we (b) HG3RA_EI

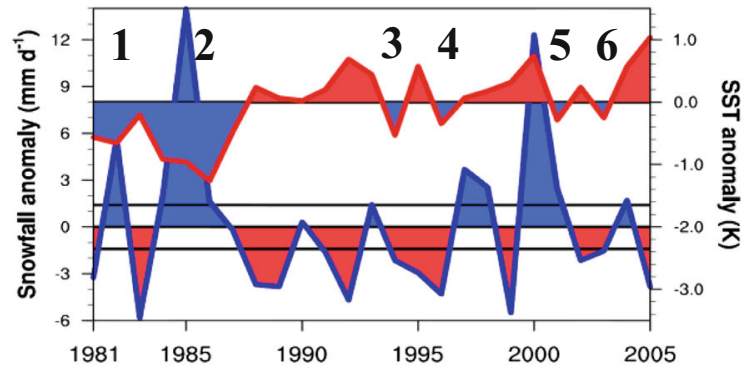

(d) HG3RA_CTL

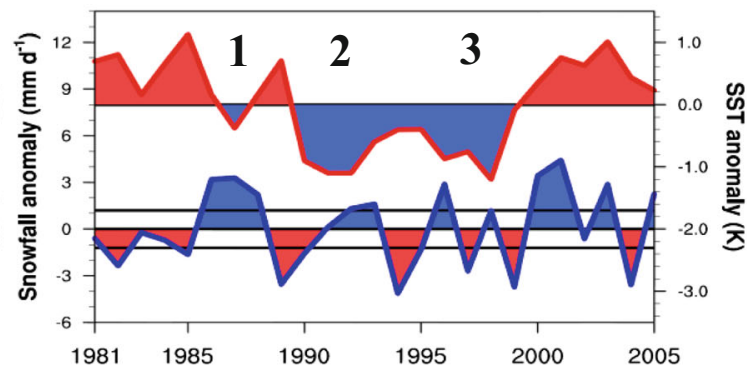

(e) HG3RA_BCVC

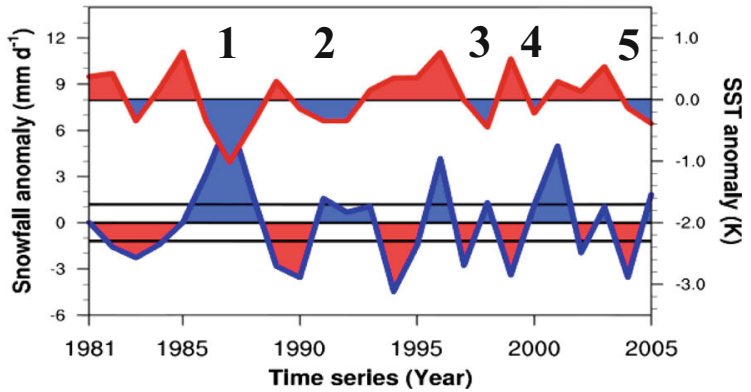

with a local significance level of $90 \%$ such as the results of Fig. 6 are plotted. Black lines correspond to the 1-sigma standard deviation and zero of snowfall anomaly and zero of SST anomaly. CC is the correlation coefficient between SST and snowfall anomaly

applied the bias- and variance-correction method described in Hoffmann et al. (2016) and investigated the impact of SST correction on precipitation and snowfall in comparison with the results of HG3RA_CTL, HG3RA_BCVC, HG2AO, and HG3RA_EI.

Even though the bias of uncorrected HadGEM2-AO SST (UC_SST) and EI_SST at some coastline is large, SST correction generally makes it decreased. The SST correction reduces the overestimation on DJF mean precipitation over East Asia region for 1981-2005. In BCR (Bias, PCC, RMSE) diagram and time series of DJF precipitation, the impact of dynamical downscaling using RCM and SST correction improves the bias of statistic amount and intra-annual variation in DJF, especially the influence of SST correction in ocean.

The influence of dynamical downscaling using RCM and SST correction produced a more similar result, that the 


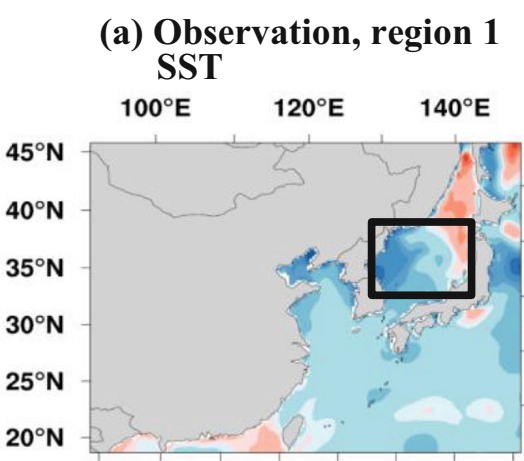

(d) Observation, region 2 SST

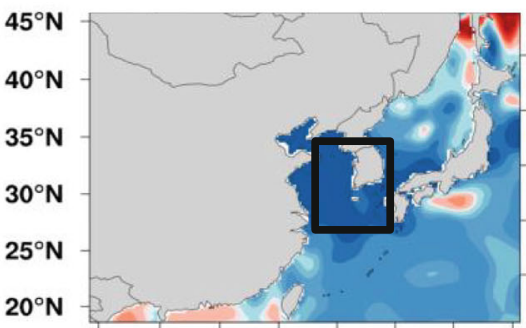

(g) HG3RA_BCVC, region 1 SST

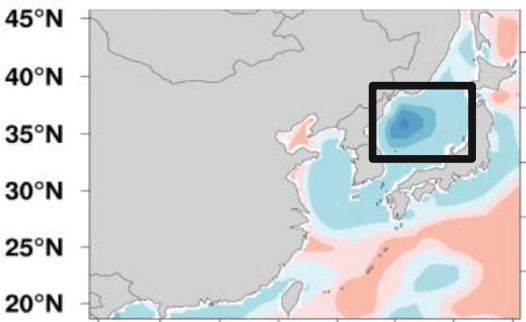

(j) HG3RA_BCVC, region 2 SST
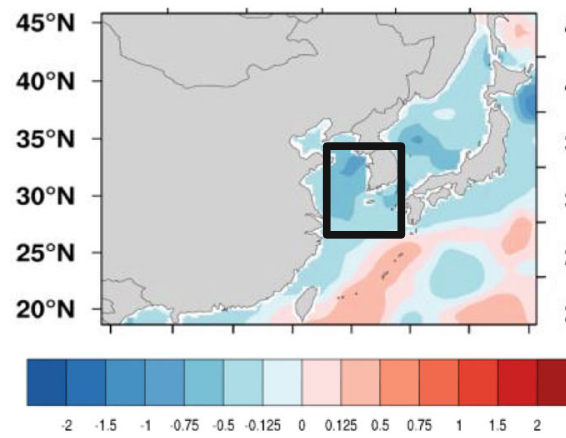

(K)

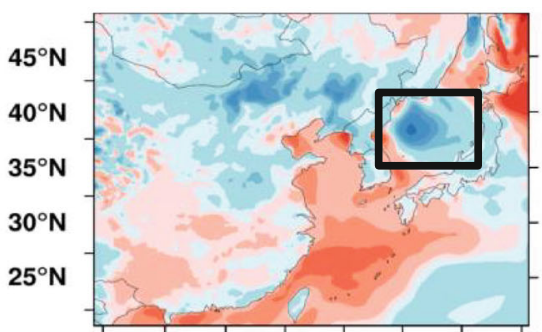

(k) HG3RA_BCVC, region 2 SSHF
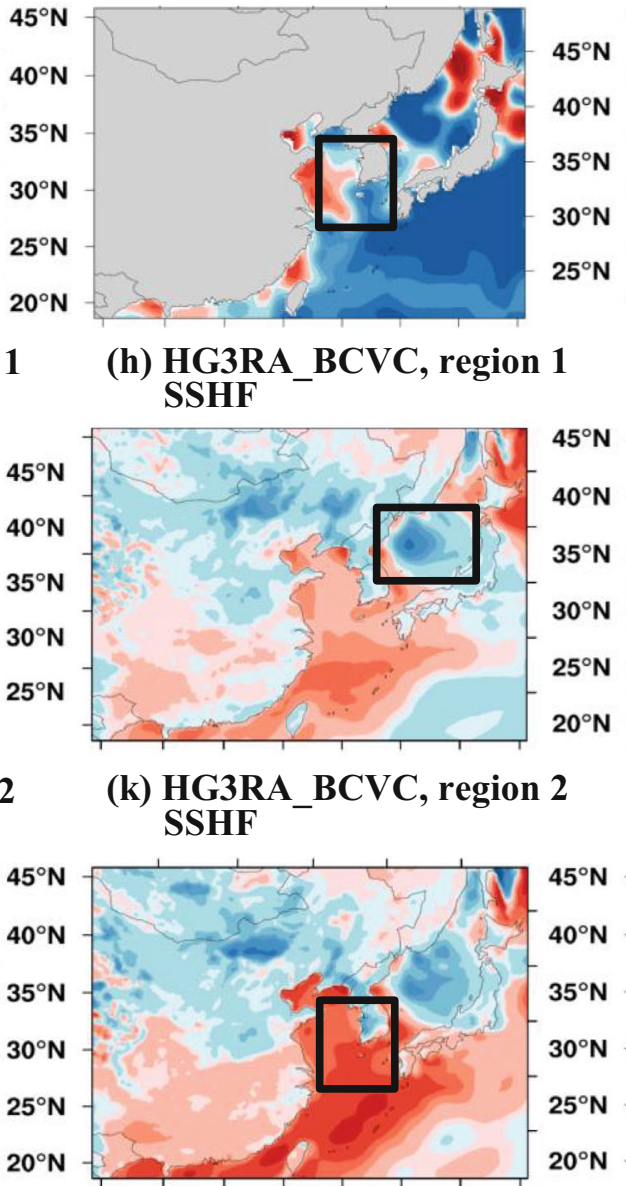

(h) HG3RA_BCVC, region 1 SSHF

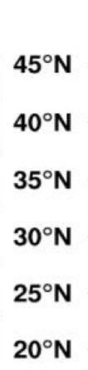

\section{(i) HG3RA_BCVC, region 1 SLHF}

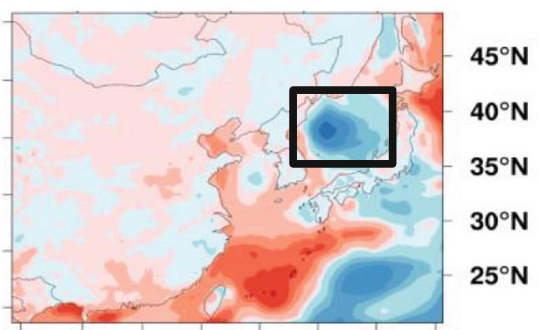

(l) HG3RA_BCVC, region 2 SLHF

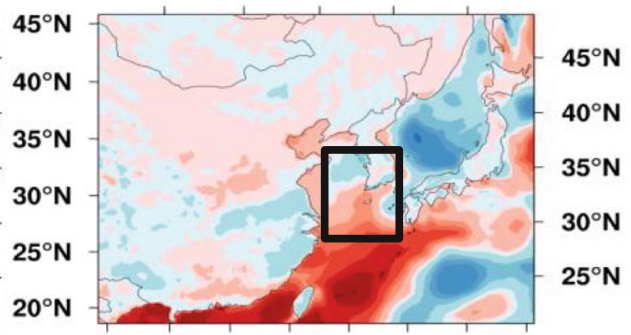

$\left(\mathrm{W} \mathrm{m}^{-2}\right)$
Fig. 8 Composite map of the difference between case 1 (the years when relatively higher SST anomaly and lower snowfall anomaly) and case 2 (the years when relatively lower SST anomaly and higher snowfall anomaly) in Fig. 7a and e of SST ( $\mathrm{K}$, left column), SSHF (W $\mathrm{m}^{-2}$, middle column), and SLHF ( $\mathrm{W} \mathrm{m}^{-2}$, right column) over East Asia region. First, second, third, and fourth row are of observation in region 1 (Fig. 7a), observation in region 2 (not shown), HG3RA_BCVC in region 1 (Fig. 7e) and HG3RA_BCVC in region 2 (not shown), respectively. The sample number for the composite is 5 . The direction which heat flux radiate from ocean is a positive value correlation coefficient between snowfall anomaly in the Korean Peninsula and SST anomaly around it shows the negative value, with the result of observation data than the result of other model data. It explains that bias- and variance- corrected SST improves the bias of variability as well as climatological mean which is on about trend.

To investigate the influence of SST correction and atmospheric field on snowfall in the negative correlation 
(a) Observation, region 1 SLP, U1000, V1000

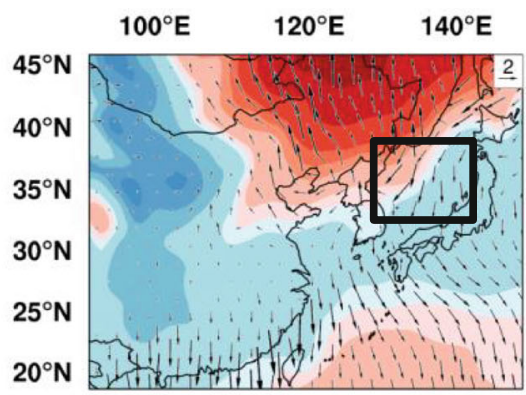

(d) Observation, region 2 SLP, U1000, V1000

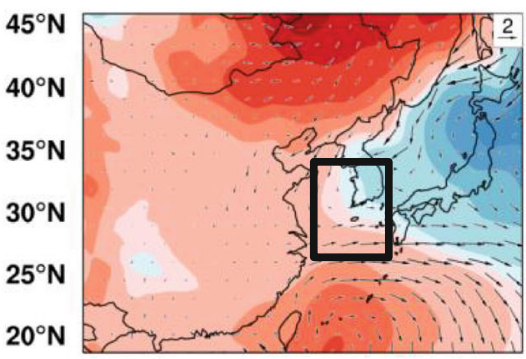

(g) HG3RA BCVC, region 1 SLP, U10̄00, V1000

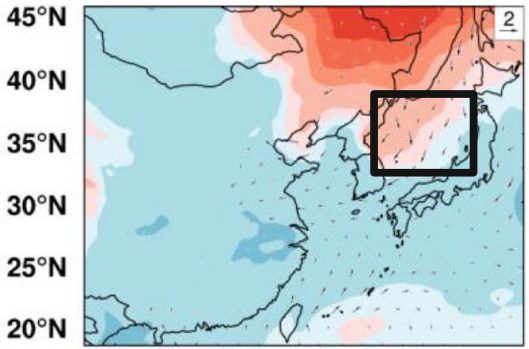

(j) HG3RA BCVC, region 2 SLP, U1000, V1000

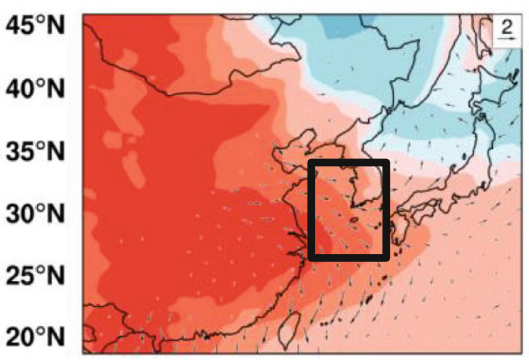

(hPa) (b) Observation, region 1 T1.5m, U1000, V1000

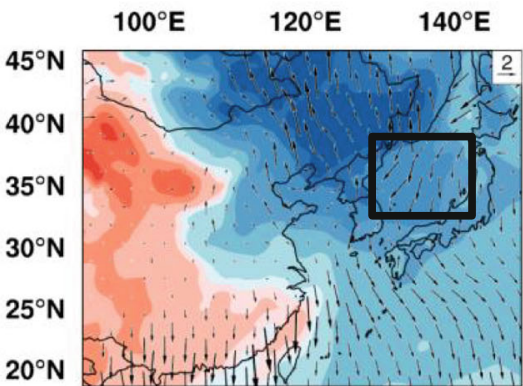

(e) Observation, region 2 T1.5m, U1000, V1000

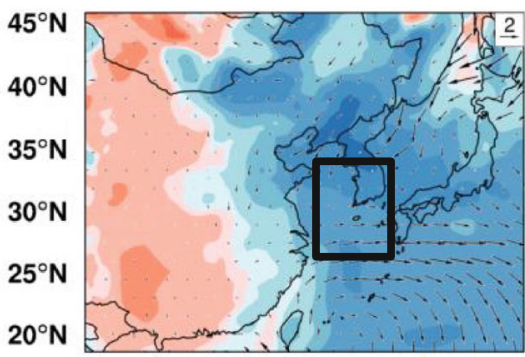

(h) HG3RA BCVC, region 1 T1.5m, U1000, V1000

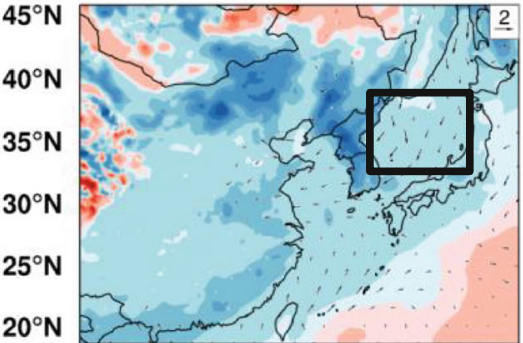

(k) HG3RA BCVC, region 2 T1.5m, U1000, V1000
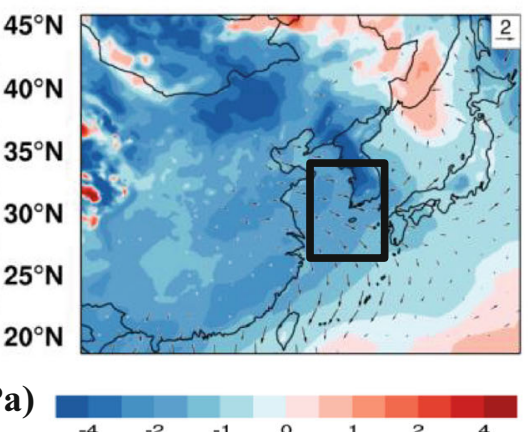

(c) Observation, region 1 MHA850, U850, V850

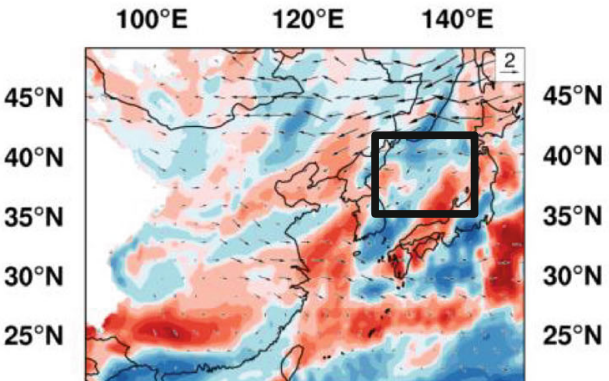

(f) Observation, region 2 MHA850, U850, V850

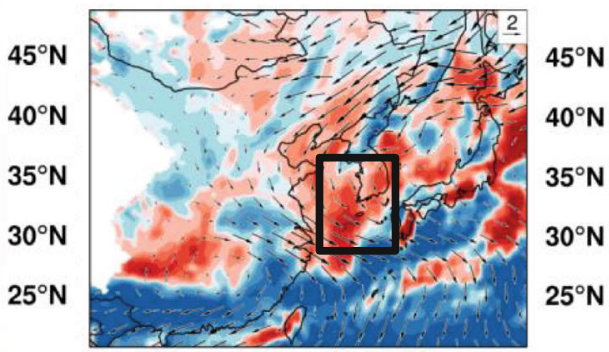

(i) HG3RA_BCVC, region 1 MHA850, U850, V850

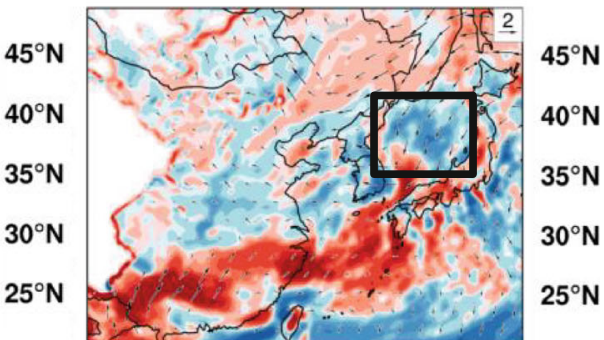

(I) HG3RA BCVC, region 2 MHA850, U850, V850

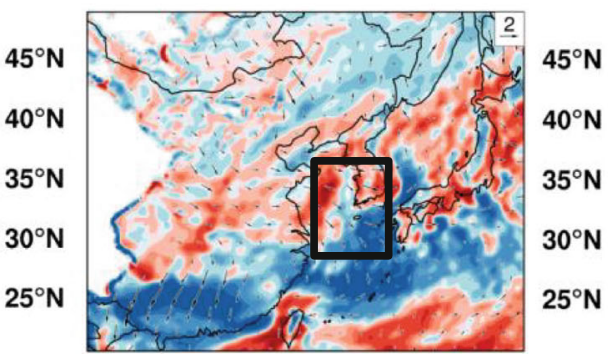

(K)

\section{ow \\ $5^{\circ} \mathrm{N}$ ${ }^{\circ} \mathrm{N}$ $5^{\circ} \mathrm{N}$} . 
in the Korean Peninsula governed by atmospheric fields and SST around the Korean Peninsula mainly affects the snowfall as the source of it.

In this study, we could understand the application of biasand variance-corrected SST as well as dynamical downscaling on regional climate simulation of wintertime precipitation and snowfall over East Asia using HadGEM3-RA. In company with this, we could realize the limitation (i.e., the existence of bias on precipitation and the time lag on SST variation) of SST correction and the importance of atmospheric fields. So the performance of regional climate simulation should be advanced through the complemented SST correction method, the improvement and the increase of the number of the GCM forcing used as the LBC of RCM, multi-GCMs or multi-RCMs ensemble approach, and applying ocean-atmosphere coupled RCM (Sasaki et al. 2005; Cha et al. 2016a; Oh et al. 2016; Suh et al. 2016; Zou and Zhou 2017).

Acknowledgements This work was funded by the Korea Meteorological Administration Research and Development Program "Research and Development for KMA Weather, Climate, and Earth system ServicesSupport to Use of Development and Application of Methodology for Climate change Prediction" under Grant (KMA2018-00321). We acknowledge with thanks Prof. Dong-Hyun Cha of the UNIST for supporting model set-up and Song-yee Hong for producing the data of HG3RA-EI experiment.

Open Access This article is licensed under a Creative Commons Attribution 4.0 International License, which permits use, sharing, adaptation, distribution and reproduction in any medium or format, as long as you give appropriate credit to the original author(s) and the source, provide a link to the Creative Commons licence, and indicate if changes were made. The images or other third party material in this article are included in the article's Creative Commons licence, unless indicated otherwise in a credit line to the material. If material is not included in the article's Creative Commons licence and your intended use is not permitted by statutory regulation or exceeds the permitted use, you will need to obtain permission directly from the copyright holder. To view a copy of this licence, visit http://creativecommons.org/licenses/by/4.0/.

\section{References}

Adler, R.F., Coauthors: The version 2 global precipitation climatology project (GPCP) monthly precipitation analysis (1979-present). J. Hydrometeorol. 4, 1147-1167 (2003)

Andermann, C., Bonnet, S., Gloaguen, R.: Evaluation of precipitation data sets along the Himalayan front. Geochem. Geophys. Geosyst. 12(7), Q07023 (2011). https://doi.org/10.1029/2011GC003513

Ao, J., Sun, J.: The impact of boreal autumn SST anomalies over the South Pacific on boreal winter precipitation over East Asia. Adv. Atmos. Sci. 33(5), 644-655 (2015). https://doi.org/10.1007/s00376015-5067-x

Ashfaq, M., Skinner, C.B., Diffenbaugh, N.S.: Influence of SST biases on future climate change projection. Clim. Dyn. 36, 1303-1319 (2011). https://doi.org/10.1007/s00382-010-0875-2

Baek, H.J., Coauthors: Climate change in the 21 st century simulated by HadGEM2-AO under representative concentration pathways. Asia-
Pac. J. Atmos. Sci. 49(5), 603-618 (2013). https://doi.org/10.1007/ s13143-013-0053-7

Banacos, P.C., Schultz, D.M.: The use of moisture flux convergence in forecasting convective initiation: historical and operational perspectives. Weather Forecast. 20, 351-366 (2005)

Best, M.J., Coauthors: The joint UK land environment simulator (JULES), model description - part 1: energy and water fluxes. Geosci. Model Dev. 4, 677-699 (2011). https://doi.org/10.5194/ gmd-4-677-2011

Bi, D., Coauthors: The ACCESS coupled model: description, control climate and evaluation. Aust. Meteorol. Oceanogr. J. 63(1), 41-64 (2013)

Cannon, A.J., Sobie, S.R., Murdock, T.Q.: Bias correction of GCM precipitation by quantile mapping: how well do methods preserve changes in quantiles and extremes? J. Clim. 28, 6938-6959 (2015). https://doi.org/10.1175/JCLI-D-14-00754.1

Castro, C.L., Pielke Sr., R.A., Leoncini, G.: Dynamical downscaling: assessment of value retained and added using the regional atmospheric modeling system (RAMS). J. Geophys. Res. 110, D05108 (2005). https://doi.org/10.1029/2004JD004721

Cha, D.H., Lee, D.K.: Reduction of systematic errors in regional climate simulations of the summer monsoon over East Asia and the western North Pacific by applying the spectral nudging technique. J. Geophys. Res. 114, D14108 (2009). https://doi.org/10.1029/ 2008JD011176

Cha, Y.M., Lee, H.W., Lee, S.H.: Impacts of the high-resolution sea surface temperature distribution on modeled snowfall formation over the Yellow Sea during a cold-air outbreak. Weather Forecast. 26, 487-503 (2011). https://doi.org/10.1175/WAF-D-10-05019.1

Cha, D.H., Jin, C.S., Moon, J.H., Lee, D.K.: Improvement of regional climate simulation of east Asian summer monsoon by coupled airsea interaction and large-scale nudging. Int. J. Climatol. 36, 334 345 (2016a). https://doi.org/10.1002/joc.4349

Cha, D.H., Lee, D.K., Coauthors: Future changes in summer precipitation in regional climate simulations over the Korean peninsula forced by multi-RCP scenarios of HadGEM2-AO. Asia-Pac. J. Atmos. Sci. 52(2), 139-149 (2016b). https://doi.org/10.1007/s13143-016$0015-\mathrm{y}$

Cheong, S.H., Byun, K.Y., Lee, T.Y.: Classification of snowfalls over the Korean peninsula based on developing mechanism. Atmosphere. 16(1), 33-48 (2006) (in Korean with English abstract)

Choi, Y.W., Ahn, J.B.: Impact of Cumulus Parameterization Schemes on the Regional Climate Simulation for the Domain of CORDEX-East Asia Phase 2 Using WRF Model. Atmosphere. 27, 105-118 (2017) (in Korean with English abstract)

Choi, J.W., Lee, J.G.: A sensitivity study of WRF model simulations to nudging methods for a Yeongdong heavy snowfall event. Atmosphere. 25, 99-115 (2015) (in Korean with English abstract)

Clack, D.B., Coauthors: The joint UK land environment simulator (JULES), model description - part 2: carbon fluxes and vegetation dynamics. Geosci. Model Dev. 4, 701-722 (2011). https://doi.org/ 10.5194/gmd-4-701-2011

Corney, S., Grose, M., Bennett, J.C., White, C., Katzfey, J., McGregor, J., Holz, G., Bindoff, N.L.: Performance Smith of downscaled regional climate simulations using a variable-resolution regional climate model: Tasmania as a test case. J. Geophys. Res. Atmos. 118, 11, 936-11,950 (2013). https://doi.org/10.1002/2013JD020087

Cusack, S., Slingo, A., Edwards, J.M., Wild, M.: The radiative impact of a simple aerosol climatology on the Hadley centre atmospheric GCM. Q. J. R. Meteorol. Soc. 124, 2517-2526 (1998). https://doi. org/10.1002/qj.49712455117

Cusack, S.S., Edwards, J.M., Kershaw, R.: Estimating the subgrid variance of saturation, and its parameterization for use in a GCM cloud scheme. Mon. Weather Rev. 125, 3057-3076 (1999). https://doi.org/ 10.1002/qj.49712556013 
Dado, J.M.B., Takahashi, H.G.: Potential impact of sea surface temperature on rainfall over the western Philippines. Earth Planet. Sci. 4(23), 1-12 (2017). https://doi.org/10.1186/s40645-017-0137-6

Davies, T., Cullen, M.J.P., Malcolm, A.J., Mawson, M.H., Staniforth, A., White, A.A., Wood, N.: A new dynamical core for the met Office's global and regional modelling of the atmosphere. Q. J. R. Meteorol. Soc. 131, 1759-1782 (2005)

Dee, D.P., Coauthors: The ERA-interim reanalysis: configuration and performance of the data assimilation system. Q. J. R. Meteorol. Soc. 137, 553-597 (2011)

Edwards, J.M., Slingo, A.: Studies with a flexible new radiation code. I: choosing a configuration for a large-scale model. Q. J. R. Meteorol. Soc. 122, 689-719 (1996). https://doi.org/10.1002/qj.49712253107

Fan, K., Tian, B.Q.: Prediction of wintertime heavy snow activity in Northeast China. Chin. Sci. Bull. 58, 1420-1426 (2013). https:// doi.org/10.1007/s11434-012-5505-7

Feser, F., Rockel, B., von Storch, H., Winterfeldt, J., Zahn, M.: Regional climate models add value to global model data. Bull. Am. Meteorol. Soc. 92(9), 1181-1192 (2011)

Fu, C.B., Wang, S.Y., Xiong, Z., Gutowski, W.J., Lee, D.K., McGregor, J.L., Sato, Y., Kato, H., Kim, J.W., Suh, M.S.: Regional climate model intercomparison project for Asia. Bull. Am. Meteorol. Soc. 86, 257-266 (2005)

Gampe, D., Ludwig, R.: Evaluation of gridded precipitation data products for hydrological applications in complex topography. Hydrology. 2017(4), 1-21 (2017). https://doi.org/10.3390/hydrology4040053

Gao, Y.H., Xue, Y., Peng, W., Kang, H.S., Waliser, D.: Assessment of dynamic downscaling of the extreme rainfall over East Asia using a regional climate model. Adv. Atmos. Sci. 28, 1077-1098 (2011). https://doi.org/10.1007/s00376-010-0039-7

Giorgi, F., Jones, C., Asrar, G.: Addressing climate information needs at the regional level: the CORDEX framework. WMO Bull. 58, 175183 (2009)

Giorgi, F., Im, E.S., Coppola, E., Diffenbaugh, N.S., Gao, X.J., Matiotti, L., Shi, Y.: Higher hydroclimatic intensity with global warming. J. Clim. 24, 5309-5324 (2011)

Grant, A.L.M., Brown, A.R.: A similarity hypothesis for shallowcumulus transports. Q. J. R. Meteorol. Soc. 125, 1913-1936 (1999). https://doi.org/10.1002/qj.49712555802

Gregory, D., Rowntree, P.R.: A mass flux convection scheme with representation of cloud ensemble characteristics and stability-dependent closure. Mon. Weather Rev. 118, 1483-1506 (1990)

Grose, M.R., Bhend, J., Argueso, D., Ekström, M., Dowdy, A., Hoffmann, P., Evans, J.P., Timbal, B.: Comparison of various climate change projections of eastern Australian rainfall. Aust. Meteorol. Oceanogr. J. 65, 72-89 (2015)

Hewitt, H.T., Coauthors: Design and implementation of the infrastructure of HadGEM3: the next-generation met Office climate modeling system. Geosci. Model Dev. 4, 223-253 (2011). https://doi.org/10. 5194/gmd-4-223-2011

Hoffmann, P., Katzfey, J.J., McGregor, J.L., Thatcher, M.: Bias and variance correction of sea surface temperatures used for dynamical downscaling. J. Geophys. Res. Atmos. 121, 12,877-12,890 (2016). https://doi.org/10.1002/2016JD025383

Hong, S.Y., Chang, E.C.: Spectral nudging sensitivity experiments in a regional climate model. Asia-Pac. J. Atmos. Sci. 48, 345-355 (2012). https://doi.org/10.1007/s13143-012-0033-3

Hong, S.Y., Kanamitsu, M.: Dynamical downscaling: fundamental issues from an NWP point of view and recommendations. Asia-Pac. J. Atmos. Sci. 50, 83-104 (2014). https://doi.org/10.1007/s13143014-0029-2

Hong, S.Y., Kwon, W.T., Chung, I.U., Baek, H.J., Byun, Y.H., Cha, D.H.: A review of regional climate change in East-Asia and the Korean peninsula based on global and regional climate modeling researches. J. Clim. Chang. Res. 2(4), 269-281 (2011) (in Korean with English abstract)
Huang, Q., Yao, S., Zhang, Y.: Analysis of local air-sea interaction in East Asia using a regional air-sea coupled model. J. Clim. 25, 767-776 (2012)

IPCC, 2014: Climate Change 2014: Impacts, Adaptation, and Vulnerability. Part B: Regional Aspects. Contribution of Working Group II to the Fifth Assessment Report of The Intergovernmental Panel on Climate Change. Barros, V. R. et al. Eds., Cambridge University press, $688 \mathrm{pp}$.

Jeong, J.I., Park, R.: A study of $\mathrm{f}$ the effects of SST deviations on heavy snowfall over the Yellow Sea. Atmosphere. 23(2), 161-169 (2013) (in Korean with English abstract)

Jeong, J.I., Park, R.J., Cho, Y.K.: Effect of sea surface temperature errors on snowfall in WRF: a case study of a heavy snowfall event in Korea in December 2012. Terr. Atmos. Ocean. Sci. 25(6), 827837 (2014). https://doi.org/10.3319/TAO.2014.08.15.01(A)

Jung, S.H., Im, E.S., Han, S.O.: The effect of topography and sea surface temperature on heavy snowfall in the Yeongdong region: a case study with high resolution WRF simulation. Asia-Pac. J. Atmos. Sci. 48(3), 259-273 (2012). https://doi.org/10.1007/s13143-0120026-2

Kang, H.S., Tangang, F., Krishnan, R.: Regional climate downscaling over Asia-Pacific region. Asia-Pac. J. Atmos. Sci. 52(2), 77 (2016). https://doi.org/10.1007/s13143-016-0023-y

Katzfey, J.J., et al.: High-resolution projections simulations for Vietnam - methodology and evaluation of current climate. AsiaPac. J. Atmos. Sci. 52, 91-106 (2016). https://doi.org/10.1007/ s13143-016-0011-2

Katzfey, J. J., J. L. McGregor, K. C. Nguyen, and M. Thatcher, 2009: Dynamical downscaling techniques: impacts on regional climate change signals. In MODSIM09 international congress on Modelling and simulation, edited by R. S. Anderssen, R. D. Braddock and L. T. H. Newham, Modelling and simulation Society of Australia and new Zealand and International Association for Mathematics and Computers in simulation, 23772383

Kim, T., Jin, E.K.: Impact of an interactive ocean on numerical weather prediction: a case of a local heavy snowfall event in eastern Korea. J. Geophys. Res. Atmos. 121, 8243-8253 (2016). https://doi.org/10. 1002/2016JD024763

Kim, J.E., Kwon, T.Y., Lee, B.Y.: Characteristics of sensible heat and latent heat fluxes over the East Sea related with Yeongdong heavy snowfall events. Ocean Polar Res. 27(3), 237-250 (2005) (in Korean with English abstract)

Kim, J.H., Sanjay, J., Mattmann, C., Boustani, M., Ramarao, M.V.S., Krishnan, R., Waliser, D.: Uncertainties in estimating spatial and interannual variations in precipitation climatology in the IndiaTibet region from multiple gridded precipitation dataets. Int. J. Climatol. 35, 4557-4573 (2015). https://doi.org/10.1002/joc.4306

Kim, J.H., Kim, Y., Wang, G.: Impact of boundary condition changes on regional climate projections over West Africa. J. Geophys. Res. Atmos. 122, 5600-5615 (2017a). https://doi.org/10.1002/ 2016JD026167

Kim, T.J., Suh, M.S., Oh, S.G.: Impact of land surface and cumulus parameterization schemes on the simulation skills of RegCM4.0 over CORDEX-East Asia phase 2 domain. Bound.-layer meteor. J. Clim. Res. 12(2), 181-197 (2017b) (in Korean with English abstract)

Kimoto, M.: Simulated chaonge of the east Asian circulation under the global warming scenario. Geophys. Res. Lett. 32, L16701 (2005). https://doi.org/10.1029/2005GL023383

Lee, J.G., Kim, Y.J.: A numerical simulation study using WRF of a heavy snowfall event in the Yeongdong coastal area in relation to the northeasterly. Atmosphere. 18(4), 339-354 (2008) (in Korean with English abstract) 
Lee, J.G., Lee, J.S.: A numerical study of Yeongdong heavy snowfall events associated with easterly. Atmosphere. 39(4), 475-490 (2003) (in Korean with English abstract)

Lee, S.H., Ryu, C.S.: Influence of continuous satellite-based SST distribution on heavy snowfall events over the Korean peninsula. Int. J. Remote Sens. 31(11), 2853-2883 (2010)

Leung, L.R., Mearns, L.O., Giorgi, F., Wilby, R.L.: Regional climate research needs and opportunities. Bull. Am. Meteorol. Soc. 84(1), 89-95 (2003)

Lock, A.P., Brown, A.R., Bush, M.R., Martin, G.M., Smith, R.N.B.: A new boundary layer mixing scheme - part 1: scheme description and single-column model tests. Mon. Weather Rev. 128, 3187-3199 (2000)

Martin, G.M., Coauthors: The HadGEM2 family of met Office unified model climate configurations. Geosci. Model Dev. 4, 723-757 (2011). https://doi.org/10.5194/gmd-4-723-2011

McAvaney, B.J., Coauthors: Model evaluation. In: Houghton, J.T., et al. (eds.) Climate Change 2001: The Scientific Basis, pp. 474-526. Cambridge University Press, Cambridge (2001)

McGregor, J.L.: Semi-Lagrangian advection on conformal-cubic grids. Mon. Weather Rev. 124, 1311-1322 (1996)

McGregor, J.L.: Geostrophic adjustment for reversibly staggered grids. Mon. Weather Rev. 133, 1119-1128 (2005a)

McGregor, J.L.: C-CAM: geometric aspects and dynamical formulation [electronic publication]. CSIRO Atmos. Res. Tech. Pap. 70, 43 (2005b)

McGregor, J.L., Dix, M.R.: An updated description of the conformalcubic atmospheric model. In: Hamilton, K., Ohfuchi, W. (eds.) High resolution simulation of the atmosphere and ocean, pp. 5176. Springer, Heidelberg (2008)

Oh, S.G., Park, J.H., Lee, S.H., Suh, M.S.: Assessment of the RegCM4 over East Asia and future precipitation change adapted to the RCP scenarios. J. Geophys. Res. Atmos. 119(6), 2913-2927 (2014)

Oh, S.G., Suh, M.S., Lee, Y.S., Ahn, J.B., Cha, D.H., Lee, D.K., Hong, S.Y., Min, S.K., Park, S.C., Kang, H.S.: Projections of high resolution climate changes for South Korea using multiple-regional climate models based on four RCP scenarios. Part 2: precipitation. Asia-Pac. J. Atmos. Sci. 52(2), 171-189 (2016). https://doi.org/10. 1007/s13143-016-0018-8

Park, J.H., Oh, S.G., Suh, M.S.: Impacts of boundary conditions on the precipitation simulation of RegCM4 in the CORDEX East Asia domain. J. Geophys. Res. Atmos. 118(4), 1652-1667 (2013)

Paul, S., Liu, C.M., Chen, J.M., Lin, S.H.: Development of a statistical downscaling model for projecting monthly rainfall over East Asia from a general circulation model output. J. Geophys. Res. Atmos. 113, D15117 (2008). https://doi.org/10.1029/2007JD009472

Piani, C., Weedon, G.P., Best, M., Gomes, S.M., Viterbo, P., Hagemann, S., Haerter, J.O.: Statistical bias correction of global simulated daily precipitation and temperature for the application of hydrological models. J. Hydrol. 395(3), 199-215 (2010)

Rayner, N.A., Parker, D.E., Horton, E.B., Folland, C.K., Alexander, L.V., Rowell, D.P., Kent, E.C., Kaplan, A.: Global analyses of sea surface temperature, sea ice, and night marine air temperature since the late nineteenth century. J. Geophys. Res. 108(D14), 4407 (2003). https:// doi.org/10.1029/2002JD002670

Reynolds, R.W.: A real-time global sea surface temperature analysis. J. Clim. 1, 75-86 (1988)

Reynolds, R. W., 2009: What's New in Version 2. OISST Webpage. [Available at http://www.ncdc.noaa.gov/sites/default/files/ attachments/Reynolds2009_oisst_daily_v02r00_version2-features. pdf]

Reynolds, R.W., Smith, T.M., Liu, C., Chelton, D.B., Casey, K.S., Schlax, M.G.: Daily high-resolution blended analyses for sea surface temperature. J. Clim. 20, 5473-5496 (2007)
Rummukainen, M.: Added value in regional climate modeling. WIREs Clim. Chang. 2016(7), 145-159 (2016). https://doi.org/10.1002/ wcc. 378

Sasaki, H., Kurihara, K., Takayabu, I., Murazaki, K., Sato, Y., Tsujino, H.: Preliminary results from the coupled atmosphere-ocean regional climate model at the meteorological research institute. J. Meteor. Soc. Japan. 84, 389-403 (2005)

Smith, R.N.: A scheme for predicting layer clouds and their water content in a general circulation model. Q. J. R. Meteorol. Soc. 116, 371-386 (1990)

Suh, M.S., Oh, S.G.: Impact of boundary conditions on the simulation of atmospheric fields using RegCM4 over CORDEX East Asia. Atmosphere. 6(6), 783-804 (2015) (in Korean with English abstract)

Suh, M.S., Oh, S.G., Lee, Y.S., Ahn, J.B., Cha, D.H., Lee, D.K., Hong, S.Y., Min, S.K., Park, S.C., Kang, H.S.: Projections of high resolution climate changes for South Korea using multiple-regional climate models based on four RCP scenarios. Part 1: surface air temperature. Asia-Pac. J. Atmos. Sci. 52(2), 151-169 (2016). https:// doi.org/10.1007/s13143-016-0017-9

Takahashi, H.G., Idenaga, T.: Impact of SST on precipitation and snowfall on the sea of Japan side in the winter monsoon season: timescale dependency. J. Meteor. Soc. Japan. 91(5), 639-653 (2013). https:// doi.org/10.2151/jmsj.2013-506

Takahashi, H.G., Ishizaki, N.N., Kawase, H., Hara, M., Yoshikane, T., Ma, X., Kimura, F.: Potential impact of sea surface temperature on winter precipitation over the Japan Sea side of Japan: a regional climate modeling study. J. Meteor. Soc. Japan. 91(4), 471-488 (2013). https://doi.org/10.2151/jmsj.2013-404

Takano, Y., Tachibana, Y., Iwamoto, K.: Influences of large-scale atmospheric circulation and local sea surface temperature on convective activity over the sea of Japan in December. SOLA. 4, 113-116 (2008). https://doi.org/10.2151/sola.2008-029

Thevakaran, A., McGregor, J.L., Katzfey, J., Hoffmann, P., Suppiah, R., Sonnadara, D.U.J.: An assessment of CSIRO conformal cubic atmospheric model simulations over Sri Lanka. Clim. Dyn. 46, 18611875 (2016). https://doi.org/10.1007/s00382-015-2680-4

von Storch, H., Langerberg, H., Feser, F.: A spectral nudging technique for dynamical downscaling purposes. Mon. Weather Rev. 128, 3664-3673 (2000)

Walters, D.N., et al.: The Met Office Unified Model global atmosphere 3.0/3.1 and JULES global land 3.0/3.1 configurations. Geosci. Model Dev. 4, 919-941 (2011). https://doi.org/10.5194/gmd-4919-2011

Wang, L., Chen, W.: Equiratio cumulative distribution function matching as an improvement to the equidistant approach in bias correction of precipitation. Atmos. Sci. Lett. 15, 1-6 (2014). https://doi.org/10. $1002 /$ asl 2.454

Wang, H.J., He, S.P.: The increase of snowfall in the Norttheast China after the mid-1980s. Chin. Sci. Bull. 58, 1350-1354 (2013). https:// doi.org/10.1007/s11434-012-5508-1

Webster, S., Brown, A.R., Cameron, D.R., Jones, C.P.: Improvements to the representation of orography in the met Office unified model. Q. J. R. Meteorol. Soc. 129, 1989-2010 (2003). https://doi.org/10. 1256/qj.02.133

Wilson, D., Ballard, S.P.: A microphysically based precipitation scheme for the UK meteorological office unified model. Mon. Weather Rev. 125, 1607-1636 (1999). https://doi.org/10.1002/qj49712555707

Wood, N., Coauthors: An inherently mass-conserving semi-implicit semi-Lagrangian discretization of the deep-atmosphere global non-hydrostatic equations. Q. J. R. Meteorol. Soc. 140, 1505 1520 (2013)

Yamamoto, M., Hirose, N.: APHRODITE: influence of assimilated SST on regional atmospheric simulation: a case of a cold-air outbreak over the Japan Sea. Atmos. Sci. Lett. 9, 13-17 (2008). https://doi. org/10.1002/asl.164 
Yatagai, A., Kamiguchi, K., Arakawa, O., Hamada, A., Yasutomi, N., Kitoh, A.: APHRODITE: constructing a long-term daily gridded precipitation dataset for Asia based on a dense network of rain gauges. Bull. Am. Meteorol. Soc. 93(9), 1401-1415 (2012)

Yeo, J.H., Ha, K.J.: A case study on causes and characteristics of the local snowstorm in Jeju Island during 23 January 2016. Atmosphere. 27(2), 177-188 (2017) (in Korean with English abstract)

Yhang, Y.B., Sohn, S.J., Jung, I.W.: Application of dynamical and statistical downscaling to east Asian summer precipitation for finely resolved datasets. Adv. Meteorol. 2017, ID2956373 (2017). https:// doi.org/10.1155/2017/2956373
Zhou, W., Tang, J., Wang, X., Wang, S., Niu, X., Wang, Y.: Evaluation of regional climate simulations over the CORDEX-EA II domain using the COSMO-CLM model. Asia-Pac. J. Atmos. Soc. 52(2), 107-127 (2016)

Zou, L., Zhou, T.: Dynamical downscaling of east Asian winter monsoon changes with a regional ocean-atmosphere coupled model. Q. J. R. Meteorol. Soc. 143, 2245-2259 (2017). https://doi.org/10.1002/qj.3082

Publisher's Note Springer Nature remains neutral with regard to jurisdictional claims in published maps and institutional affiliations. 